\title{
Unexpected High Photothemal Conversion Efficiency of Gold Nanospheres upon Grafting with Two-Photon Luminescent Ruthenium(II) Complexes: A Way Towards Cancer Therapy?
}

Zhang, Pingyu ; Wang, Jinquan ; Huang, Huaiyi ; Yu, Bole ; Qiu, Kangqiang ; Huang, Juanjuan ; Wang, Shutao ; Jiang, Lei ; Gasser, Gilles ; Ji, Liangnian ; Chao, Hui

DOI: https://doi.org/10.1016/j.biomaterials.2015.06.012

Posted at the Zurich Open Repository and Archive, University of Zurich ZORA URL: https://doi.org/10.5167/uzh-114203

Journal Article

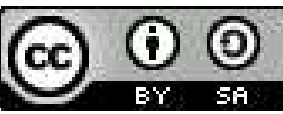

The following work is licensed under a Creative Commons: Attribution-ShareAlike 4.0 International (CC BY-SA 4.0) License.

Originally published at:

Zhang, Pingyu; Wang, Jinquan; Huang, Huaiyi; Yu, Bole; Qiu, Kangqiang; Huang, Juanjuan; Wang, Shutao; Jiang, Lei; Gasser, Gilles; Ji, Liangnian; Chao, Hui (2015). Unexpected High Photothemal Conversion Efficiency of Gold Nanospheres upon Grafting with Two-Photon Luminescent Ruthenium(II) Complexes: A Way Towards Cancer Therapy? Biomaterials, 63:102-114.

DOI: https://doi.org/10.1016/j.biomaterials.2015.06.012 


\section{Unexpected High Photothemal Conversion Efficiency of Gold} Nanospheres upon Grafting with Two-Photon Luminescent Ruthenium(II) Complexes: A Way Towards Cancer Therapy?

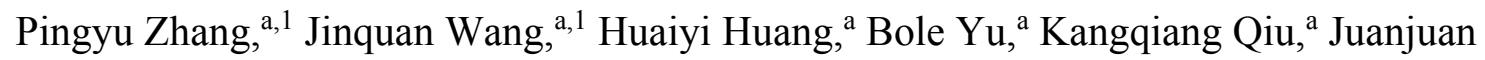
Huang, ${ }^{a}$ Shutao Wang, ${ }^{\mathrm{b}}$ Lei Jiang, ${ }^{\mathrm{c}}$ Gilles Gasser, ${ }^{\mathrm{d}}$ Liangnian Ji, ${ }^{\mathrm{a}}$ and Hui Chao ${ }^{\mathrm{a}, *}$

${ }^{a}$ MOE Key Laboratory of Bioinorganic and Synthetic Chemistry, School of Chemistry and Chemical Engineering, Sun Yat-Sen University, Guangzhou 510275, P. R. China ${ }^{b}$ Laboratory of Bio-inspired Smart Interface Science, Technical Institute of Physics and Chemistry, Chinese Academy of Sciences, Beijing 100190, P. R. China

${ }^{c}$ Beijing National Laboratory of Molecular Sciences, Key Laboratory of Organic Solid, Institute of Chemistry Chinese Academy of Sciences, Beijing 100190, P. R. China

${ }^{d}$ Department of Chemistry, University of Zurich, Winterthurerstrasse 190, CH-8057, Zurich, Switzerland.

*Corresponding Author. Tel: +86 20 84110613; Fax: +86 20 84112245; E-mail address: ceschh@mail.sysu.edu.cn.

${ }^{1}$ These authors contributed equally to this work. 


\begin{abstract}
The design and development of functional hybrid nanomaterials is currently a topic of great interest in biomedicine. Herein we investigated the grafting of Ru(II) polypyridyl complexes onto gold nanospheres (Ru@AuNPs) to improve the particles' near infrared (NIR) absorption, and ultimately allow for application in photothermal cancer therapy. As demonstrated in this article, these ruthenium(II) complexes could indeed significantly enhance gold nanospheres' two-photon luminescence (PTL) intensity and photothermal therapy (PTT) efficiency. The best dual functional nanoparticles of this study were successfully used for real-time luminescent imaging-guided PTT in live cancer cells. Furthermore, in vivo tumor ablation was achieved with excellent treatment efficacy under a diode laser $(808 \mathrm{~nm})$ irradiation at the power density of $0.8 \mathrm{~W} / \mathrm{cm}^{2}$ for $5 \mathrm{~min}$. This study demonstrates that the coupling of inert $\mathrm{Ru}(\mathrm{II})$ polypyridyl complexes to gold nanospheres allows for the enhancement of two-photon luminescence and for efficient photothermal effect.
\end{abstract}

Keywords: Photothermal; Two-photon luminescence; Ru(II) complex; Gold nanospheres

\title{
1. Introduction
}

Photothermal therapy (PTT) uses photon absorbers to convert optical energy into thermal energy to kill cancer cells. PTT has recently received extensive attention among researchers[1-11]. Gold nanoparticles are the most widely explored class of nanoagents due to their low toxicity and good biocompatibility. These properties make gold nanoparticles a promising platform for various biomedical applications, particularly for cancer diagnosis and treatment[12-14]. Over the past several years, gold nanorods[15] and nanoshells[16]-based near infrared (NIR) hyperthermia agents have been employed to photothermally kill cancer cells. However, gold nanorods have a low photostability since their NIR absorbance peak diminishes after a significant period of laser irradiation due to the "melting effect" [17]. Also, gold nanoshells are too large (diameter $>100 \mathrm{~nm}$ ) for tissue accumulation and elimination[18].

Gold nanospheres (AuNPs) have significant advantages over other nanoparticles due 
to their small size, rapid synthesis and easy bioconjugation to various ligands such as DNA, peptides, antibodies and small guest molecules. These properties make them especially attractive as biological sensors[19,20]. However, the poor NIR absorbance of naked gold nanospheres limits their application in photothermal therapy[21,22]. It was recently demonstrated that aggregated gold nanospheres[23] and hollow gold nanospheres[24] can serve as agents for photothermal cancer therapy. However, the "melting effect" still occurs upon irradiation with a strong laser and the generated photothermal heat often melting hollow or anisotropic $\mathrm{Au}$ nanostructures into solid spheres, which indicates poor photothermal stability and thus easy loss of NIR surface plasmon resonance (SPR) properties. Herein, we propose a new strategy involving the adsorption of molecules with strong two-photon absorption onto the surface of AuNPs as antenna species to improve the particles' NIR absorption, and ultimately allow for photothermal cancer therapy.

$\mathrm{Ru}(\mathrm{II})$ polypyridyl complexes, owing to their more diverse stereochemistry than organic compounds, water-solubility, large Stokes shifts, good photostability and strong two-photon luminescence (TPL), have emerged as novel and promising candidates for biological probing and environmental monitoring[25-28]. To date, a few luminescent $\mathrm{Ru}(\mathrm{II})$ complex-functionalized AuNPs have been developed[29-33], and two examples of $\mathrm{Ru}(\mathrm{II})$-functionalized AuNPs have been used for one-photon luminescent cellular imaging in living cells[31,33]. However, to the best of our knowledge, there is no report of the impact of Ru complexes on the efficiency of photothermal therapy or two-photon property of gold nanomaterials. More specifically, in this paper, we study: (1) how do the TPL and PTT of gold nanoparticles change after grafting terminal phenanthroline groups of $\mathrm{Ru}(\mathrm{II})$ complexes of various length (Fig. 1); (2) how does the size of these hybrid nanoparticles influence their PTT efficiency and TPL. The results showed that Ru(II) complexes can improve the AuNPs' photothermal therapy efficiency and the two-photon luminescence in a significant manner.

\section{Materials and methods}

\subsection{Materials and instruments}


Ruthenium chloride hydrate (Alfa Aesar, USA), bpy (2,2'-bipyridine, Sigma Aldrich, USA), MTT (3-(4,5-dimethylthiazol-2-yl)-2,5-diphenyltetrazoli-um bromide, Sigma Aldrich, USA), DMSO (dimethyl sulfoxide, Sigma Aldrich, USA), Rhodamine B (Sigma-Aldrich, USA) and DPBF (1,3-diphenyliso-benzofuran, Sigma Aldrich, USA) were used as received. Water with a resistivity of $18.2 \mathrm{M} \Omega \cdot \mathrm{cm}$, which was used throughout the experiments, was purified with a Milli-Q system from the Millipore Company (USA). The complex $\left[\mathrm{Ru}(\mathrm{bpy})_{2}(\mathrm{pdppz})\right] \mathrm{Cl}_{2}(\mathbf{R u} \mathbf{2}$, bpy = 2,2'-bipyridine, pdppz $=$ phenanthro[4,5-abc]dipyrido[3,2-h:2', 3'-j]phenazine) was synthesised as previously described by our group[34].

Microanalysis $(\mathrm{C}, \mathrm{H}$, and $\mathrm{N})$ were carried out on a Vario EL cube elemental analyzer. ${ }^{1} \mathrm{H}$ NMR spectra were recorded on a Varian INOVA500NB NMR spectrometer with $\left(\mathrm{CD}_{3}\right)_{2} \mathrm{SO}$ as solvent at room temperature. All chemical shifts are given relative to tetramethylsilane (TMS). Electrospray ionization mass spectra (ESI-MS) were recorded on an LCQ system (Finnigan MAT, USA). The morphology and the microstructure of the $\mathrm{Ru} @$ AuNPs were characterized by transmission electron microscopy (TEM, JEM2010-HR, 200 KV), energy dispersive X-ray spectrometer (EDX, S-520/INCA 300, Japan) and field-emission scanning electron microscope (FE-SEM, JSM-6330F). The X-ray photoelectron spectroscopy (XPS, ESCALab250, Thermo VG) with $200 \mathrm{~W}$ A1 KR radiation in twin anode. All core level XPS spectra were calibrated using $C_{1 s}$ photoelectron peak at $284.6 \mathrm{eV}$ as the reference. Dynamic light scattering and zeta potential experiments were determined by dynamic laser light scattering equipment (DLS, Brooken Haven BI-200SM). The average hydrodynamic diameter and the zeta potential of the Ru@AuNPs were measured 6 times for each solution, with the average of all the runs reported. UV-Vis-NIR spectra were recorded on a UV-3150 spectrophotometer (Shimadzu). Emission spectra were recorded on a PerkineElmer LS55 spectrofluorophotometer at room temperature. A diode laser $(808 \mathrm{~nm})$ from Hi-Tech Optoelectronics Co., Ltd. (Beijing, China) and Xenon Light Source (450 nm, MAX-302, ASAHI Spectra, USA) were used in this study.

\subsection{Synthesis and characterization}

\subsubsection{Synthesis of 2-diethoxymethyl-1H-imidazo[1,10]-phenanthroline (PIPOEt)}


To a solution of sodium ethoxide $(0.6 \mathrm{~g}, 26.1 \mathrm{mmol}$ of $\mathrm{Na}$ in $20 \mathrm{~mL}$ dry ethanol) were added 1,10-phenanthroline-5,6-diamine ( $2.7 \mathrm{~g}, 12.7 \mathrm{mmol}$ ) and ethyl diethoxyacetate $(2.7 \mathrm{~g}, 15.1 \mathrm{mmol})$. The mixture was refluxed for $24 \mathrm{~h}$, cooled to room temperature, and the solvent was removed under vacuum. The residue was dissolved in water, neutralized with acetic acid, and extracted with ethyl acetate. The combined organics were dried over anhydrous sodium sulfate, filtered, and evaporated to dryness. The residue was subjected to flash column chromatography $\left(\mathrm{CHCl}_{3} / \mathrm{EtOAc}=2: 1\right)$. Yield: $78 \% .{ }^{1} \mathrm{H} \mathrm{NMR}(500 \mathrm{MHz}$, $\left.\mathrm{CDCl}_{3}-\mathrm{d}_{6}\right): \delta 9.45(\mathrm{~d}, J=8.0 \mathrm{~Hz}, 2 \mathrm{H}), 9.18(\mathrm{~d}, J=8.5 \mathrm{~Hz}, 1 \mathrm{H}), 7.60(\mathrm{dd}, J=8.5 \mathrm{~Hz}, 1 \mathrm{H})$, $5.48(\mathrm{~s}, 1 \mathrm{H}), 3.49-3.70(\mathrm{~m}, 4 \mathrm{H}), 1.26(\mathrm{t}, 6 \mathrm{H}, J=8.0 \mathrm{~Hz})$. ESI-MS $\left(\mathrm{CH}_{3} \mathrm{OH}\right) \mathrm{m} / z: 323$ $[\mathrm{M}+\mathrm{H}]^{+}$.

\subsubsection{Synthesis of 1H-imidazo[1,10]-phenanthroline-2-carbaldehyde (PIPCHO)}

Water $(6 \mathrm{~mL})$ and $37 \%$ hydrochloride acid $(3 \mathrm{ml})$ were added to a THF $(20 \mathrm{~mL})$ solution of 2-diethoxymethyl-1H-imidazo[1,10]-phenanthroline (1.3 g, $4.0 \mathrm{mmol})$. After refluxing for $24 \mathrm{~h}$, the reaction mixture was neutralized with saturated sodium bicarbonate and extracted with EtOAc $(3 \times 70 \mathrm{~mL})$. The extract was washed with brine $(2 \times 50 \mathrm{~mL})$, filtered, and evaporated to dryness. The residue was chromatographed on silica gel (Hexane/EtOAc 1:3). Yield: 78\%. ${ }^{1} \mathrm{H}$ NMR (500 MHz, $\mathrm{CDCl}_{3}-\mathrm{d}_{6}$ ): $\delta 10.35$ (s, 1H), $9.60(\mathrm{~d}, J=8.0 \mathrm{~Hz}, 2 \mathrm{H}), 9.34(\mathrm{~d}, J=7.5 \mathrm{~Hz}, 1 \mathrm{H}), 7.83(\mathrm{dd}, J=8.0 \mathrm{~Hz}, 1 \mathrm{H})$. ESI-MS $\left(\mathrm{CH}_{3} \mathrm{OH}\right) m / z: 248[\mathrm{M}+\mathrm{H}]^{+}$.

\subsubsection{Synthesis of $\left[\mathrm{Ru}(\text { bpy })_{2}(\mathrm{PIPCHO})\right]\left(\mathrm{ClO}_{4}\right)_{2}$}

cis-[Ru(bpy $\left.)_{2} \mathrm{Cl}_{2}\right] \cdot 2 \mathrm{H}_{2} \mathrm{O} \quad(0.2 \mathrm{~g}, 0.4 \mathrm{mmol})$ and $1 \mathrm{H}$-imidazo[1,10]-phenanthroline -2-carbaldehyde $(0.1 \mathrm{~g}, 0.4 \mathrm{mmol})$ in ethanediol $(10 \mathrm{~mL})$ were heated to $125^{\circ} \mathrm{C}$ for $8 \mathrm{~h}$ under $\mathrm{N}_{2}$. The cooled reaction mixture was diluted with water $(30 \mathrm{~mL})$. Saturated aqueous sodium perchlorate solution was added under vigorous stirring and filtered. The dark red solid was collected and washed with small amounts of water, and diethyl ether, then dried under a vacuum and purified by column chromatography on alumina with acetonitrile-toluene $(5: 1 \mathrm{v} / \mathrm{v})$ as the eluant. The solvent was removed under reduced pressure, and red microcrystals were obtained. Yield: 80\%. Anal. Calcd for $\mathrm{C}_{34} \mathrm{H}_{24} \mathrm{~N}_{8} \mathrm{Cl}_{2} \mathrm{O} 9 \mathrm{Ru}(\%): \mathrm{C}, 47.45 ; \mathrm{H}, 2.81 ; \mathrm{N}, 13.02$; Found (\%): C, 47.34; H, 2.78; N, 
13.10. ${ }^{1} \mathrm{H}$ NMR (500 MHz, DMSO-d6): $\delta 13.62$ (s,1H, NH), 10.4 (s, 1H, CHO), 9.22 (d, $J=8.5 \mathrm{~Hz}, 2 \mathrm{H}), 8.87(\mathrm{~d}, J=8.0 \mathrm{~Hz}, 2 \mathrm{H}), 8.53(\mathrm{~m}, 4 \mathrm{H}), 8.34(\mathrm{~d}, J=7.5 \mathrm{~Hz}, 2 \mathrm{H}), 8.11(\mathrm{~d}$, $J=8.0 \mathrm{~Hz}, 2 \mathrm{H}), 7.81(\mathrm{~m}, 4 \mathrm{H}), 7.52(\mathrm{t}, J=8.0 \mathrm{~Hz}, 4 \mathrm{H}), 7.19(\mathrm{t}, J=7.5 \mathrm{~Hz}, 2 \mathrm{H})$. ESI-MS $\left(\mathrm{CH}_{3} \mathrm{OH}\right) \mathrm{m} / z: 331\left[\mathrm{M}-2 \mathrm{ClO}_{4}\right]^{2+}, 662\left[\mathrm{M}-2 \mathrm{ClO}_{4}+\mathrm{H}\right]^{+}$.

\subsubsection{Synthesis of $\left[R u(b p y)_{2}(B P I P)\right] C l_{2}(\boldsymbol{R u} \mathbf{1})$}

9,10-phenanthrenequinone $(0.1 \mathrm{~g}, 0.5 \mathrm{mmol})$, [Ru(bpy) $2(\mathrm{PIPCHO})]\left(\mathrm{ClO}_{4}\right)_{2}(0.42 \mathrm{~g}$, $0.5 \mathrm{mmol})$ and ammonium acetate $(0.5 \mathrm{~g}, 6.0 \mathrm{mmol})$ in glacial acetic acid $(10 \mathrm{~mL})$ heated at $120^{\circ} \mathrm{C}$ for $4 \mathrm{~h}$ under an argon atmosphere. The solvent was removed under vacuum. The residue was then dissolved in water. The separated solid filtered and dried to give a red solid. The solid was then purified by column chromatography on alumina using acetonitrile-toluene $(8: 1 \mathrm{v} / \mathrm{v})$ as the eluant. The complex was then converted to the chloride salt by dissolving the perchlorate complex in a minimum amount of acetone. This step is then followed by the slow addition of a saturated solution of tetrabutylammonium chloride in acetone. The chloride salt, which precipated, was filtered, washed with acetone and dried in vacuo. Yield: 85.1\%. Anal. Calcd for $\mathrm{C}_{46} \mathrm{H}_{30} \mathrm{~N}_{12} \mathrm{Cl}_{2} \mathrm{O} 8 \mathrm{Ru}(\%): \mathrm{C}, 52.58 ; \mathrm{H}, 2.88 ; \mathrm{N}, 16.00 ;$ Found (\%): C, 52.48; H, 2.79; N, 16.12; ${ }^{1} \mathrm{H}$ NMR (500 MHz, DMSO-d6): $\delta 13.68$ (s, 1H, NH), 13.55 (s, 1H, NH) 9.11 (d, $J$ $=8.0 \mathrm{~Hz}, 2 \mathrm{H}), 8.93(\mathrm{~d}, J=7.5 \mathrm{~Hz}, 2 \mathrm{H}), 8.84(\mathrm{t}, J=8.5 \mathrm{~Hz}, 4 \mathrm{H}), 8.29(\mathrm{~d}, J=7.5 \mathrm{~Hz}, 4 \mathrm{H})$, $8.21(\mathrm{t}, J=7.0 \mathrm{~Hz}, 4 \mathrm{H}), 8.10(\mathrm{t}, J=7.5 \mathrm{~Hz}, 2 \mathrm{H}), 8.01(\mathrm{~m}, 2 \mathrm{H}), 7.82(\mathrm{~d}, J=7.0 \mathrm{~Hz}, 2 \mathrm{H})$, 7.59 (dd, $J=8.0 \mathrm{~Hz}, 4 \mathrm{H}), 7.34(\mathrm{t}, J=8.0 \mathrm{~Hz}, 2 \mathrm{H}) .{ }^{13} \mathrm{C}$ NMR (126 MHz, DMSO-d6): $\delta 163.11,157.23,156.99,152.73,152.48,152.19,151.90,151.69,146.88,146.74,145.04$, $138.61,138.48,136.16,133.24,131.64,130.27,128.42,128.25,127.57,125.01,124.75$, 121.24, 120.06. ESI-MS $\left(\mathrm{CH}_{3} \mathrm{OH}\right) \mathrm{m} / z: 426\left[\mathrm{M}-2 \mathrm{Cl}_{2}\right]^{2+}, 852\left[\mathrm{M}-2 \mathrm{Cl}_{2}+\mathrm{H}\right]^{+}$.

\subsubsection{Synthesis of 2-(4-bromophenyl)-1H-imidazo[4,5-f][1,10]-phenanthroline (PIPBr)}

9,10-phenanthrenequinone $(0.21 \mathrm{~g}, 1.0 \mathrm{mmol})$, 4-bromobenzaldehyde $(0.185 \mathrm{~g}, 1.0$ mmol) and ammonium acetate $(0.95 \mathrm{~g}, 12.2 \mathrm{mmol})$ in glacial acetic acid $(10 \mathrm{~mL})$ were heated for $4 \mathrm{~h}$ at $120^{\circ} \mathrm{C}$, the cooled reaction mixture was neutralized with ammonia and then filtered off to give a pale yellow solid. The solid was recrystallized in ethanol. Yield: 80.5\%. Anal. Calcd for $\mathrm{C}_{19} \mathrm{H}_{11} \mathrm{BrN}_{4}$ : C, 60.82; H, 2.95; N, 14.93; Found: C, 60.91; H, 
2.87; N, 14.80. ${ }^{1} \mathrm{H}$ NMR (500 MHz, $\left.\mathrm{CDCl}_{3}-\mathrm{d}_{6}\right): \delta 8.93(\mathrm{~d}, J=8.3 \mathrm{~Hz}, 2 \mathrm{H}), 8.54(\mathrm{~d}, J=$ $8.5 \mathrm{~Hz}, 2 \mathrm{H}), 7.82(\mathrm{t}, J=8.4 \mathrm{~Hz}, 2 \mathrm{H}), 7.75(\mathrm{~d}, J=7.8 \mathrm{~Hz}, 2 \mathrm{H}), 7.62(\mathrm{~m}, J=8.0 \mathrm{~Hz}, 2 \mathrm{H})$. ESI-MS $\left(\mathrm{CH}_{3} \mathrm{OH}\right) \mathrm{m} / z: 376[\mathrm{M}+\mathrm{H}]^{+}$.

\subsubsection{Synthesis of $\left[\mathrm{Ru}(\mathrm{bpy})_{2}(\mathrm{PIPBr})\right]\left(\mathrm{ClO}_{4}\right)_{2}$}

cis-[Ru(bpy $\left.)_{2} \mathrm{Cl}_{2}\right] \cdot 2 \mathrm{H}_{2} \mathrm{O}(0.2 \mathrm{~g}, 0.4 \mathrm{mmol})$ and $\mathbf{P I P B r}(0.15 \mathrm{~g}, 0.4 \mathrm{mmol})$ in ethanediol $(10 \mathrm{~mL})$ were heated to $125^{\circ} \mathrm{C}$ for $8 \mathrm{~h}$ under $\mathrm{N}_{2}$. The cooled reaction mixture was then diluted with water $(30 \mathrm{~mL})$. Saturated aqueous sodium perchlorate solution was added under vigorous stirring and the precipitate filtered. The dark red solid was collected and washed with small amounts of water and diethyl ether. It was then dried under vacuum and purified by column chromatography on alumina using acetonitrile-toluene $(3: 1 \mathrm{v} / \mathrm{v})$ as the eluant to obtain red microcrystals. Yield: $85.1 \%$. Anal. Calcd for $\mathrm{C}_{39} \mathrm{H}_{27} \mathrm{~N}_{8} \mathrm{BrCl}_{2} \mathrm{O} 8 \mathrm{Ru}(\%)$ : C, 47.43; H, 2.76; N, 11.35; Found (\%): C, 47.61; H, 2.61; N, 11.46. ${ }^{1} \mathrm{H}$ NMR (500 MHz, DMSO-d6): $\delta 9.03(\mathrm{~d}, J=8.0 \mathrm{~Hz}, 2 \mathrm{H}), 8.83(\mathrm{dd}, J=$ $8.0 \mathrm{~Hz}, 4 \mathrm{H}), 8.22(\mathrm{~m}, 4 \mathrm{H}), 8.08(\mathrm{t}, J=8.5 \mathrm{~Hz}, 2 \mathrm{H}), 7.97(\mathrm{~d}, J=8.0 \mathrm{~Hz}, 2 \mathrm{H}), 7.82(\mathrm{~d}, J=$ $8.5 \mathrm{~Hz}, 4 \mathrm{H}), 7.56(\mathrm{t}, J=8.5 \mathrm{~Hz}, 4 \mathrm{H}), 7.32$ (t, $J=7.5 \mathrm{~Hz}, 2 \mathrm{H}), 7.18$ (m, 2H). ESI-MS $\left(\mathrm{CH}_{3} \mathrm{OH}\right) \mathrm{m} / z: 394\left[\mathrm{M}-2 \mathrm{ClO}_{4}\right]^{2+}, 788\left[\mathrm{M}-2 \mathrm{ClO}_{4}+\mathrm{H}\right]^{+}$.

\subsubsection{Synthesis of $\left[\mathrm{Ru}(\text { bpy })_{2}(\mathrm{PIPBCHO})\right]\left(\mathrm{ClO}_{4}\right)_{2}$}

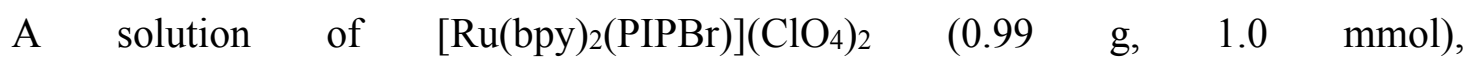
4-(diphenylamino)phenylboronic acid (0.37 g, $1.6 \mathrm{mmol}), \mathrm{Pd}\left(\mathrm{PPh}_{3}\right)_{4}(0.061 \mathrm{~g}, 0.053$ mmol), and aqueous $\mathrm{Na}_{2} \mathrm{CO}_{3}(2 \mathrm{M}, 4 \mathrm{~mL})$ in toluene $(8 \mathrm{~mL})$ and ethanol $(3 \mathrm{~mL})$ were heated to reflux under an argon atmosphere for $24 \mathrm{~h}$. The solution was cooled to room temperature and concentrated by rotary evaporation. Water was added under vigorous stirring and the precipitate filtered off. The residue was purified by column chromatography on alumina using acetonitrile-toluene $(10: 1 \mathrm{v} / \mathrm{v})$ as the eluant. Yield: 72.1\%. Anal. Calcd for $\mathrm{C}_{46} \mathrm{H}_{32} \mathrm{~N}_{8} \mathrm{Cl}_{2} \mathrm{O}_{9} \mathrm{Ru}(\%)$ : C, 54.55; H, 3.18; N, 11.06; Found (\%): C, 54.41; H, 3.31; N, 11.30. ${ }^{1} \mathrm{H}$ NMR (500 MHz, DMSO-d6): $\delta 13.6(\mathrm{~s}, 1 \mathrm{H}), 10.2(\mathrm{~s}, 1 \mathrm{H})$, $9.15(\mathrm{~d}, J=8.0 \mathrm{~Hz}, 2 \mathrm{H}), 9.02(\mathrm{~d}, J=8.5 \mathrm{~Hz}, 4 \mathrm{H}), 8.86(\mathrm{~d}, J=7.5 \mathrm{~Hz}, 4 \mathrm{H}), 8.28(\mathrm{~m}, 4 \mathrm{H})$, $8.02(\mathrm{t}, J=8.5 \mathrm{~Hz}, 2 \mathrm{H}), 7.83(\mathrm{dd}, J=8.0 \mathrm{~Hz}, 4 \mathrm{H}), 7.67(\mathrm{dd}, J=8.0 \mathrm{~Hz}, 4 \mathrm{H}), 7.50(\mathrm{~m}$, 4H), $7.38(\mathrm{t}, J=7.5 \mathrm{~Hz}, 2 \mathrm{H})$. ESI-MS $\left(\mathrm{CH}_{3} \mathrm{OH}\right) \mathrm{m} / \mathrm{z}: 407\left[\mathrm{M}-2 \mathrm{ClO}_{4}\right]^{2+}, 813$ 
$\left[\mathrm{M}-2 \mathrm{ClO}_{4}+\mathrm{H}\right]^{+}$.

\subsubsection{Synthesis of $\left[R u(b p y)_{2}(P I P B P)\right] C l_{2}(\mathbf{R u 3})$}

9,10-phenanthrenequinone $(0.1 \mathrm{~g}, 0.5 \mathrm{mmol})$, [Ru(bpy) $\left.)_{2}(\mathrm{PIPBCHO})\right]\left(\mathrm{ClO}_{4}\right)_{2}(0.51 \mathrm{~g}$, $0.5 \mathrm{mmol})$ and ammonium acetate $(0.5 \mathrm{~g}, 6.0 \mathrm{mmol})$ in glacial acetic acid $(10 \mathrm{~mL})$ heated at $120^{\circ} \mathrm{C}$ for $4 \mathrm{~h}$ under an argon atmosphere. The solvent was removed under vacuum. The residue was then dissolved in water. The separated solid was filtered off and dried to give a red solid. The solid was purified by column chromatography on alumina with acetonitrile-methanol $(10: 1 \mathrm{v} / \mathrm{v})$ as the eluant. The complex was then converted to the chloride salt by dissolving the perchlorate complex in a minimum amount of acetone, followed by the slow addition of a saturated solution of tetrabutylammonium chloride in acetone. The chloride salt was filtered off, washed with acetone and dried. Yield: $72.1 \%$. Anal. Calcd for $\mathrm{C}_{58} \mathrm{H}_{38} \mathrm{~N}_{12} \mathrm{Cl}_{2} \mathrm{O} 8 \mathrm{Ru}(\%)$ : C, 57.91; H, 3.18; N, 13.97; Found (\%): C, 57.71; H, 3.14; N, 13.72. ${ }^{1} \mathrm{H}$ NMR (500 MHz, DMSO-d6): $\delta 13.68$ (s, 1H, NH), 13.60 (s, $1 \mathrm{H}, \mathrm{NH}), 8.35(\mathrm{~d}, J=8.5 \mathrm{~Hz}, 4 \mathrm{H}), 8.11(\mathrm{t}, J=8.0 \mathrm{~Hz}, 6 \mathrm{H}), 7.57(\mathrm{~d}, J=7.5 \mathrm{~Hz}, 2 \mathrm{H}), 7.48$ (dd, $J=8.5 \mathrm{~Hz}, 4 \mathrm{H}), 7.33(\mathrm{~m}, 5 \mathrm{H}), 7.17$ (t, $J=8.0 \mathrm{~Hz}, 3 \mathrm{H}), 7.08$ (d, $J=7.5 \mathrm{~Hz}, 2 \mathrm{H})$, $6.85(\mathrm{~m}, 8 \mathrm{H}), 6.59(\mathrm{t}, J=8.5 \mathrm{~Hz}, 2 \mathrm{H}) .{ }^{13} \mathrm{C}$ NMR (126 MHz, DMSO-d 6$): \delta$ 157.26, $157.05,155.43$, 155.37, 153.33, 152.76, 151.95, 151.87, 150.32, 147.81, 145.51, 144.13, $138.44,138.28,132.72$, 132.52, 132.00, 131.92, 130.92, 130.87, 130.06, 129.74, 129.29, $129.19,128.91,128.37,128.23,127.09,126.81,125.72,124.94,124.85$. ESI-MS $\left(\mathrm{CH}_{3} \mathrm{OH}\right) \mathrm{m} / \mathrm{z}: 502\left[\mathrm{M}-2 \mathrm{Cl}_{2}\right]^{2+}, 1004\left[\mathrm{M}-2 \mathrm{Cl}_{2}+\mathrm{H}\right]^{+}$.

\subsubsection{Synthesis of the Ru@AuNPs}

The phase transfer was realized by a modification of the Brust two-phase synthesis. $\mathrm{HAuCl}_{4} \cdot 3 \mathrm{H}_{2} \mathrm{O}(3.87 \mathrm{mg}, 10 \mu \mathrm{mol})$ was first solubilized in water $(1 \mathrm{~mL})$ and was then transferred to the toluene $(2 \mathrm{~mL})$ phase using tetraoctylammoniumbromide $(9 \mathrm{mg}, 16.5$ $\mu$ mol $)$ as the phase-transfer agent. $\mathrm{NaBH}_{4}$ in water $\left(0.1 \mathrm{~mol} \mathrm{~L}{ }^{-1}\right.$-sample A, $0.2 \mathrm{~mol}$ $\mathrm{L}^{-1}$-sample B, $0.4 \mathrm{~mol} \mathrm{~L}^{-1}$-sample $\mathrm{C}, 0.8 \mathrm{~mol} \mathrm{~L}^{-1}$ - sample $\mathrm{D}$ ) was then added at once to the previous toluene solution. The resulting mixture was then stirred for $1 \mathrm{~h}$. The three complexes Ru1, Ru2, Ru3 $(4.93 \mu \mathrm{mol})$ in water $(10 \mathrm{~mL})$ were finally added and the resulting mixture was stirred for $1 \mathrm{~h}$. The initial orange aqueous solution turned to dark 
brown confirming the phase transfer of the the Ru@AuNPs from toluene to the aqueous solution. A dialysis procedure was used to remove the unreacted reagents with 3500 molecular weight cutoff dialysis membrane. The nanoparticles were then centrifuged at $15000 \mathrm{rpm}$ for $1 \mathrm{~h}$.

\subsection{Determination of two-photon absorption cross sections}

The two-photon absorption spectra of the probes were determined over a broad spectral region by the typical two-photon induced fluorescence (TPF) method relative to Rhodamine B in methanol as the standard[35]. The two-photon fluorescence data were acquired using an OpoletteTM 355II (pulse width $\leq 100 \mathrm{fs,}, 80 \mathrm{MHz}$ repetition rate, 808 nm, Spectra Physics Inc., USA). Two-photon fluorescence measurements were performed in fluorometric quartz cuvettes with the Ru complex/Ru@AuNPs in water. The experimental fluorescence excitation and detection conditions were conducted with negligible re-absorption processes, which can affect TPA measurements. The quadratic dependence of two-photon induced fluorescence intensity on the excitation power was verified at an excitation wavelength of $808 \mathrm{~nm}$. The two-photon absorption cross section of the probes was calculated at each wavelength according to equation[35].

$$
\delta_{2}=\delta_{1} \frac{\phi_{1} C_{1} I_{2} n_{2}}{\phi_{2} C_{2} I_{1} n_{1}}
$$

where $\mathrm{I}$ is the integrated fluorescence intensity, $\mathrm{C}$ is the concentration, $\mathrm{n}$ is the refractive index, and $\Phi$ is the quantum yield. Subscript ' 1 ' stands for reference samples, and ' 2 ' stands for samples.

\subsection{Deterimination of the number of Ru molecules per gold nanoparticle}

The Ru@AuNPs were completely digested by $5 \mathrm{~mL}$ of aqua regia at $50{ }^{\circ} \mathrm{C}$. The solution was evaporated to $0.5 \mathrm{~mL}$ and cooled down to room temperature. Subsequently, the sample was diluted to $3 \% \mathrm{HNO}_{3}$ with Milli Q $\mathrm{H}_{2} \mathrm{O}$, and then analyzed by inductively coupled plasma mass spectrometry (ICP-MS, Thermo Elemental Co., Ltd.). Quantification was carried out by external five-point calibration. The number of $\mathrm{Ru}$ molecules per gold nanoparticle is calculated as follows[36]:

$$
N_{A u N P s}=\frac{m_{\text {AuNPs }}}{\rho_{A u} V_{\text {AuNPs }}}
$$




$$
\begin{gathered}
V_{A u N P s}=\frac{4}{3} \pi \gamma^{3} \\
N_{R u}=n_{R u} \cdot N_{A}=\frac{m_{R u}}{M_{R u}} \cdot N_{A} \\
R=\frac{N_{R u}}{N_{A u N P s}}
\end{gathered}
$$

m: measured density of ions (atoms) from ICP/MS analysis $(\mathrm{g} / \mathrm{L})$

$\rho:$ density of $\mathrm{Au}$

$\gamma:$ the radius of naked AuNPs

n: molar number

$\mathrm{M}:$ molecular weight $(\mathrm{g} / \mathrm{mol})$

$\mathrm{R}$ : atomic percentage of Ru to AuNPs

\subsection{Photothermal effect measurements}

For photothermal measurements, $100 \mu \mathrm{L}$ of the Ru@Au nanoparticles solutions at the same concentration $(50 \mu \mathrm{g} / \mathrm{mL})$ was placed in a series of specimen cuvettes and each cuvette was irradiated by an $808 \mathrm{~nm}$ laser $\left(0.8 \mathrm{~W} / \mathrm{cm}^{2}, 5 \mathrm{~min}\right)$. Light-induced temperature change in the solutions was collected by using a thermal camera (MAG30, Magnity Electronics, Thermal Imaging Expert). Pure AuNPs were measured as the control groups, and a total of three replicates were conducted for each sample. The photothermal conversion efficiency of Ru@AuNPs was determined according to the method[37].

\subsection{Singlet oxygen detection}

Singlet oxygen sensor (DPBF), that is highly selective for singlet oxygen, was used to evaluate the singlet oxygen generation (SOG) of the Ru2@AuNPs. The concentration of the Ru2@AuNPs was fixed a $50 \mu \mathrm{g} / \mathrm{mL}$. The mixture solutions were irradiated with an $808 \mathrm{~nm}$ laser $\left(0.8 \mathrm{~W} / \mathrm{cm}^{2}\right)$ or a $450 \mathrm{~nm}$ Xenon lamp at different irradiation times. DPBF was dissolved in water containing $2 \%$ methanol with a final concentration of $10 \mu \mathrm{M}$. DPBF fluorescence emission was produced using an excitation wavelength of $405 \mathrm{~nm}$. The fluorescence intensity at $479 \mathrm{~nm}$ was recorded as a function of irradiation time. The sample's SOG was evaluated by the DPBF fluorescence enhancement compared with the background or control samples.

The ${ }^{1} \mathrm{O}_{2}$ generation quantum yield $\left(\Phi_{\Delta}\right)$ was calculated according to Eqs.(6) and (7), 
where $\mathrm{I}_{\text {in }}$ is the incident monochromatic light intensity, $\Phi_{\mathrm{ab}}$ is the light absorbing efficiency, $\Phi_{\mathrm{r}}$ is the reaction quantum yield of ${ }^{1} \mathrm{O}_{2}$ with DPBF (1,3-diphenyl-isobenzofuran), $\mathrm{t}$ is the reaction time, $\mathrm{I}_{0}$ and $\mathrm{I}_{\mathrm{t}}$ are the fluorescence intensities of DPBF by the addition of Ru2@AuNPs before and after irradiation, $\mathrm{k}$ is the slope of plots (the curve of the DPBF consumption percentage at $479 \mathrm{~nm}$ as a function of irradiation time) and superscript s stands for standard[38]. The standard was $\left[\mathrm{Ru}(\mathrm{bpy})_{3}\right]^{2+}$ $\left(\Phi_{\Delta}^{\mathrm{s}}=0.81\right)[39]$.

$$
\begin{array}{r}
\frac{-\Delta[D P B F]}{t}=\frac{I_{0}-I_{t}}{t}=I_{i n} \Phi_{a b} \Phi_{\Delta} \Phi_{r} \\
\frac{k}{k^{s}}=\frac{\Phi_{a b}}{\Phi_{a b}^{s}}=\frac{\Phi_{\Delta}}{\Phi_{\Delta}^{s}}
\end{array}
$$

\subsection{Reactive oxidative species (ROS) measurement [40-42]}

The production of intracellular ROS was detected by 2 ', 7'-dichlorofluorescin diacetate ( $\mathrm{H}_{2} \mathrm{DCF}-\mathrm{DA}$, Sigma-Aldrich), a cell-permeable nonfluorescent probe which is deesterified in cell and upon oxidation turns to highlyfluorescent $2^{\prime}, 7^{\prime}$-dichlorofluorescin. HeLa cells were seeded in white 96 -well plates at a density of $1 \times 10^{4}$ cells one day before treatment. The medium was removed and $\mathrm{H}_{2}$ DCF-DA $(10 \mu \mathrm{M})$ was added to cells for 30 min at $37^{\circ} \mathrm{C}$ in the dark. The cells were subsequently washed in serum-free medium and treated for $30 \mathrm{~min}, 2 \mathrm{~h}, 4 \mathrm{~h}$, or $8 \mathrm{~h}$ with Ru2@AuNPs $(50 \mu \mathrm{g} / \mathrm{mL})$, then irradiated $5 \mathrm{~min}$ by a diode laser $\left(808 \mathrm{~nm}, 0.8 \mathrm{~W} / \mathrm{cm}^{2}\right)$ or a Xenon lamp $(450 \mathrm{~nm}, 100 \mathrm{~mW})$ in the absence or the presence of $10 \mathrm{mM} \mathrm{N}$-acetylcysteine (NAC, an antioxidant, Alfa Aesar). Fluorescence was quantified at $530 \mathrm{~nm}$ emission with $488 \mathrm{~nm}$ excitation wavelength using a microplate reader (Infinite M200 Pro, Tecan, Männedorf, Switzerland).

\subsection{Cell cultures and cytotoxicity test}

Human cervical carcinoma cancer cell lines $(\mathrm{HeLa})$ were obtained from the Center for Experimental Animals, Sun Yat-Sen University (Guangzhou, China). All cell lines were maintained in DMEM media, which supplemented with $100 \mathrm{U} / \mathrm{ml}$ penicillin.

$1 \times 10^{4}$ cells/well were seeded in a 96-well flat bottomed multi-well plate with supplemented culture medium (100 $\mu \mathrm{L} /$ well) followed by incubation with $5 \% \mathrm{CO}_{2} / 95 \%$ 
air at $37^{\circ} \mathrm{C}$ for $24 \mathrm{~h}$. After adding the serially diluted solutions of the Ru2@AuNPs, the cells were incubated with $5 \% \mathrm{CO}_{2} / 95 \%$ air at $37{ }^{\circ} \mathrm{C}$ for $12 \mathrm{~h}$. The cells were then exposed to a diode laser $(808 \mathrm{~nm})$ for $5 \mathrm{~min}$. The irradiated plates were returned to the incubator for another $12 \mathrm{~h}$. Cell viability was measured with the MTT assay. The optical density of each well was then measured using a microplate spectrophotometer at a wavelength of $590 \mathrm{~nm}$. All cytotoxicity tests were performed in parallel with negative control, which consisted of cells in the presence of the drugs without irradiation.

\subsection{Calcein AM staining}

Live cells were distinguished by the presence of ubiquitous intracellular esterase activity, as determined by the enzymatic conversion of the virtually nonfluorescent cell-permeant calcein AM to the intensely fluorescent calcein $\left(\lambda_{\mathrm{ex}}=488 \mathrm{~nm}, \lambda_{\mathrm{em}}=520 \pm\right.$ $20 \mathrm{~nm}$ ). The determination of cell viability depends on these physical and biochemical cell properties[43]. After cancer cells treatment with the Ru2@AuNPs (50 $\mu \mathrm{g} / \mathrm{mL})$ and a diode laser $(808 \mathrm{~nm})$ irradiation $\left(0.8 \mathrm{~W} / \mathrm{cm}^{2}, 5 \mathrm{~min}\right)$, and the control cells in the presence of the Ru2@AuNPs without irradiation, the cancer cells were incubated with calcein AM (2 $\mu \mathrm{M})$ solutions for $30 \mathrm{~min}$ and imaged directly using an inverted fluorescence microscope (Zeiss Axio Observer D1, Germany).

\subsection{Two-photon luminescence imaging}

HeLa cell lines were incubated with the Ru2@AuNPs $(50 \mu \mathrm{g} / \mathrm{mL})$ for $1 \mathrm{~h}$ at $37{ }^{\circ} \mathrm{C}$. After being washed with fresh PBS $(\mathrm{pH}=7.0)$ three times, the cells under real time irradiation were imaged on a Zeiss LSM 710 NLO confocal microscope $(63 \times$ oil immersion objective). The excitation wavelength of the laser was $808 \mathrm{~nm}$, and the two-photon images were integrated over the range of 580-650 nm.

\subsection{Cell uptaken analysis}

Flow Cytometry Analysis. HeLa cells at a density of $1 \times 10^{5}$ cells $/ \mathrm{mL}$ were cultured in 6-well plates for $24 \mathrm{~h}$ in an incubator, and then Ru2@AuNPs was added with fresh DMEM, which were followed by further incubation for $0.5 \mathrm{~h}$ and $1 \mathrm{~h}$, respectively. Then, 
the cells were trypsinised and washed with PBS. The cell uptake samples were analysed by a FACSCanto II (BD Biosciences, USA).

ICP-MS analysis. Exponentially grown HeLa cells were plated at a density of $1 \times 10^{4}$ cells per mL in a volume of $5 \mathrm{~mL}$ of DMEM medium. The Ru2@AuNPs were added to the culture medium (final DMSO concentration less than $0.1 \% \mathrm{v} / \mathrm{v}$ ) and incubated for varying amounts of time at $37^{\circ} \mathrm{C}$. After digestion by a trypsin-EDTA solution, the HeLa cells were counted and divided into three portions. In the first portion, the nuclei were extracted using a nucleus extraction kit (Shanghai Sangon Biological Engineering Technology \& Services Co. Ltd.); in the second portion, the cytoplasm was extracted using a cytoplasm extraction kit (Shanghai Sangon Biological Engineering Technology $\&$ Services Co. Ltd.); and in the third portion, the whole cell was used. The samples were digested with $60 \% \mathrm{HNO}_{3}$ at room temperature for one day. Each sample was diluted with MilliQ $\mathrm{H}_{2} \mathrm{O}$ to obtain $3 \% \mathrm{HNO}_{3}$ sample solutions. The standards for calibration were freshly prepared by diluting these stock solutions with $3 \% \mathrm{HNO}_{3}$ in MilliQ $\mathrm{H}_{2} \mathrm{O}$. The ruthenium concentrations in the three portions were determined using inductively coupled plasma mass spectrometry (ICP-MS Thermo Elemental Co., Ltd.).

TEM analysis. HeLa cells $\left(5 \times 10^{5}\right)$ were treated with the Ru2@AuNPs $(50 \mu \mathrm{g} / \mathrm{mL})$ at $37{ }^{\circ} \mathrm{C}$ for $1 \mathrm{~h}$. The cells were washed twice and fixed with $2 \%$ glutaraldehyde at $4{ }^{\circ} \mathrm{C}$ for $1 \mathrm{~h}$. The cells were then dehydrated with sequential washes in ethanol and embedded in Spurr's resin. The obtained ultrathin sections were mounted in copper grids, counterstained with uranyl acetate and lead citrate, and visualized in an electron microscope (TEM 100 CX, JEOL, Tokyo, Japan).

\subsection{Photothermal therapy in vivo}

Balb/c-(nu/nu) female nude mice aged 4 to 5 weeks were purchased and bred in the Center of Experiment Animal of Sun Yat-sen University. All experimental protocols were approved by the Sun Yat-sen University Animal Care and Use Committee. HeLa xenografts were established by inoculating $2 \times 10^{6}$ cells via subcutaneous injection (s.c.) into BALB/c-(nu/nu) female nude mice. When the tumor volume reached approximately $120 \mathrm{~mm}^{3}$, the nude mice were randomly allocated into six groups ( 8 mice per group) before the experiments. 
Photothermal therapy process was as followed. Group 1 (Ru2@AuNPs): mice were intratumorally injected with the Ru2@AuNPs (40 $\mu \mathrm{L} / 20 \mathrm{~g}$ body weight of $5 \mathrm{mg} / \mathrm{mL}$ solution, a dose of $200 \mu \mathrm{g}$ Ru2@AuNPs/20 g body weight); Group 2 (Ru2@AuNPs + laser): mice were intratumorally injected with the Ru2@AuNPs (40 $\mu \mathrm{L} / 20$ g body weight of $5 \mathrm{mg} / \mathrm{mL}$ solution, $200 \mu \mathrm{g}$ Ru2@AuNPs/20 g body weight); Group 3 (AuNPs + laser): mice were intratumorally injected with the AuNPs $(40 \mu \mathrm{L} / 20 \mathrm{~g}$ body weight of $5 \mathrm{mg} / \mathrm{mL}$ solution, a dose of $200 \mu \mathrm{g}$ AuNPs/20 g body weight). Group 4 (Ru2 + laser): mice were intratumorally injected with the Ru2 (40 $\mu \mathrm{L} / 20 \mathrm{~g}$ body weight of $5 \mathrm{mg} / \mathrm{mL}$ solution, a dose of $200 \mu \mathrm{g} \mathbf{R u 2} / 20 \mathrm{~g}$ body weight). Group 5 (physiological saline): mice were intratumorally injected with the same volume of physiological saline solution; Group 6 (physiological saline + laser): mice were intratumorally injected with the same volume of physiological saline solution. After the injection, each mouse of group 2, group 3, group 4, and group 6 was irradiated with a diode laser $(808 \mathrm{~nm}$, Hi-Tech Optoelectronics Co., Ltd. Beijing, China) at $0.8 \mathrm{~W} / \mathrm{cm}^{2}$ for $5 \mathrm{~min}$. Group 1 and group 5 (without laser irradiation) were used as the controls.

After the irradiation (day 0), the tumor sizes were measured using a caliper every 2 days. The mice with tumors were photographed with a digital color camera at day 0 and day 10 . The tumor volumes were calculated based on the following formula: Tumor Volume $(\mathrm{V})=$ (tumor length) $\times(\text { tumor width })^{2} / 2$. Relative tumor volumes were calculated as $\mathrm{V} / \mathrm{V}_{0}\left(\mathrm{~V}_{0}\right.$ was the initial tumor volume of Day 0$)[44,45]$.

\subsection{Histological examination}

At the end of the photothermal therapy in vivo, all the mice of the five groups were sacrificed and the organs including liver, kidney, spleen, heart, lung, brain, intestine, ovary and tumor tissue were resected. A portion of these fresh tissues were immersed in $4 \%$ paraformaldehyde at $4{ }^{\circ} \mathrm{C}$. For morphological studies, $6 \mu \mathrm{m}$ sections were obtained from paraffin-embedded samples, processed according to the standard procedures for inclusion, and rehydrated (xylene, alcohol, water). Sections were stained with hematoxylin-eosin (H\&E), Hematoxylin has a deep blue-purple color and stains nucleic acids. Eosin is pink and stains proteins nonspecifically. In a typical tissue, nuclei are stained blue, whereas the cytoplasm and extracellular matrix have varying degrees of pink staining. The sections 
were observed with an Olympus microscope to analyze the tissue structure and cell state.

\subsection{Statistical analysis}

Data were presented as mean \pm standard deviation, and significance was assessed with Student's $t$ test. Differences were considered significant at $\mathrm{P}<0.05$.

\section{Results and discussion}

\subsection{Design and synthesis}

The synthesis and characterization of the phenanthroline ligands of three different length chelating the ruthenium centre are presented in the Supporting Information (Schemes S1-S2 and Fig. S1-S6). The Ru@AuNPs were synthesized based on the two-phase method developed by Mayer et al[30]. The lone electron pairs of the nitrogen atoms in the phenantroline ligand have a strong affinity to the gold surface and form stable and water-soluble Ru@AuNPs. TEM studies showed that the Ru@AuNPs were highly monodisperse, unaggregated and spherical in shape (Fig. 2a, b and Fig. S7). Solutions of the Ru@AuNPs were stable at room temperature for a period of 3 months (Fig. S8). The size of the Ru@AuNPs is increased when the molar ratio of the reducing agent $\left(\mathrm{NaBH}_{4}\right)$ is increased (Table 1). The formation of the Ru@AuNPs upon variation of the ratio of $\mathrm{NaBH}_{4}$, was followed by UV-Vis spectroscopy (Fig. S9). While the two bands of the $\mathrm{Ru}(\mathrm{II})$ complex was observed at $365 \mathrm{~nm}$ and $458 \mathrm{~nm}$, respectively, the surface plasmon resonance (SPR) band of the citrate-AuNPs was located at $520 \mathrm{~nm}$, whereas the SPR band of the Ru@AuNPs was red shifted to $570 \mathrm{~nm}$. This indicates the formation of $\mathrm{N}-\mathrm{Au}$ bonds between the $\mathrm{Ru}(\mathrm{II})$ complex and the AuNPs. Moreover, the $\mathrm{Ru} @$ AuNPs exhibit stronger broad NIR absorption than the Ru(II) complex and the AuNPs themselves. This trait forms the foundation of the particles' photothermal effects. The elements contained in the Ru2@AuNPs were further determined via energy dispersive X-ray spectroscopy analysis (EDX) and X-ray photoelectron spectroscopy (XPS) measurements (Fig. 2c-d, Fig. S10 and Table S1). The results provided the chemical composition and the energy distribution of $\mathrm{Au} 4 \mathrm{f}, \mathrm{Ru} \mathrm{u}_{3}, \mathrm{C}_{1 \mathrm{~s}}, \mathrm{O}_{1 \mathrm{~s}}$ and $\mathrm{N}_{1 \mathrm{~s}}$, which indicated that the Ru complex was modified onto the AuNPs surface. 
The number of Ru molecules per gold nanoparticle was determined via ICP-MS, after digestion of the AuNPs in aqua regia. The calculation method is detailed in the Supporting Information. The results revealed that there were more than one hundred $\mathrm{Ru}(\mathrm{II})$ complexes per gold nanoparticle, which is a greater number than that observed for analogous systems[46,47]. As anticipated, for the same $\mathrm{Ru}(\mathrm{II})$ complex, the larger the nanoparticles are, the more $\mathrm{Ru}$ complexes per gold nanoparticle are present. In addition, the longer the spacer between the $\mathrm{Ru}(\mathrm{II})$ complex and the gold nanoparticle is, the more Ru complexes are present at the surface of the AuNPs. This is most likely due to a higher steric hindrance on the surface of gold nanoparticles. The Zeta potential of all $\mathrm{Ru} @$ AuNPs is positive and increases upon the number of $\mathrm{Ru}$ complexes present due to their positive charges (Table 1).

\subsection{Photophysical properties of the Ru@AuNPs}

We then investigated the luminescence of the Ru@AuNPs. To some extent, the luminescence of the $\mathrm{Ru}(\mathrm{II})$ complex was partly quenched due to an energy transfer from the $\mathrm{Ru}(\mathrm{II})$ complex to the AuNPs (Fig. S11 and Table 1). The quenching process is related to various factors such as the size of the nanoparticles or the distance between the AuNPs and the ruthenium complexes. For the same $\mathrm{Ru}(\mathrm{II})$ complex, the results show that the large gold nanoparticles have a higher quenching efficiency than the small nanoparticles. For the same size nanoparticles( 45 nm of Ru1@AuNPs, Ru2@AuNPs and Ru3@AuNPs), the longer the distance between photosensitiser and quencher is, the lower the quenching efficiency is $(96.5 \%$ quenching for the Ru1@AuNPs vs. the free Ru1 complex, 57.9\% quenching for the Ru2@AuNPs vs. the free Ru2 complex, and 40.5\% quenching for the Ru3@AuNPs vs. the free Ru3 complex).

Next, the two-photon luminescence (TPL) properties of the Ru@AuNPs were investigated by determining the two-photon absorption cross-section $\delta$ (TPA) of the $\mathrm{Ru}$ @AuNPs using rhodamine B as a reference (Table 1 and Fig. 3). As expected, the AuNPs alone displayed almost no TPL. However, the Ru2@AuNPs and the Ru3@AuNPs exhibit strong two-photon emission upon 808 nm excitation. The Ru2@AuNPs have the largest TPA $\left(\delta_{808 \mathrm{~nm}}=187-308\right.$ Göppert-Mayer $(\mathrm{GM}) ; 1 \mathrm{GM}=1 \times$ $10^{-50} \mathrm{~cm}^{4} \cdot \mathrm{s}^{-1} \cdot$ photon $^{-1}$ ) since $\mathrm{Ru} 2$ complex has the strongest two-photon luminescence 
$\left(\delta_{808 \mathrm{~nm}}=394 \mathrm{GM}\right)$. However, the Ru1@AuNPs exhibited the smallest TPA $\left(\delta_{808 \mathrm{~nm}}=\right.$ 7.8-18 GM) of the series due to the strongest quenching efficiency. The two-photon excitation active process was confirmed via a power dependence experiment. A log-log linear relationship between the emission intensity and incident power showed the best-fit with a gradient $(\mathrm{n} \approx 2)$ (Fig. S12). The nanoparticles' size also influenced their TPL intensity. For the same $\mathrm{Ru}(\mathrm{II})$ complex coated on the AuNPs, the two-photon luminescence decreased upon increase of the particles' size. In other words, the TPL intensity of the Ru@AuNPs is stronger than the AuNPs themselves (no TPL) because the two-photon luminescence of the $\mathrm{Ru}(\mathrm{II})$ complexes is transferred to the AuNPs. The TPL of the Ru@AuNPs mainly depends on the TPL of Ru(II) complexes, the distance between the Ru(II) complexes and the AuNPs, and the size of the Ru@AuNPs.

\subsection{Photothermal properties of the Ru@AuNPs}

We then investigated the photothermal therapy potential of our nanoparticles. For this purpose, we used a diode laser $(808 \mathrm{~nm})$ at a power density of $0.8 \mathrm{~W} / \mathrm{cm}^{2}$ to irradiate water, pure gold nanoparticles and the Ru@Au nanoparticles $(45.0 \pm 1.5 \mathrm{~nm}$ size, $100 \mu \mathrm{L}$, $50 \mu \mathrm{g} / \mathrm{mL})$ for different irradiation times $(0-5 \mathrm{~min})$. We then used a thermal imaging camera to record the temperature variation (Fig. 4). The thermal signals of pure water show no obvious change $\left(\Delta \mathrm{T}<2{ }^{\circ} \mathrm{C}\right)$. The AuNPs were shown to convert NIR light to heat $\left(\Delta \mathrm{T}=8.6-12.5^{\circ} \mathrm{C}\right.$; sample $\mathrm{D}$ in Table 1: $\left.12.5^{\circ} \mathrm{C}\right)$. However, these temperature increases $(\Delta \mathrm{T})$ were much lower than those observed for the Ru@AuNPs $(\Delta \mathrm{T}=$ 19.4-38.5 ${ }^{\circ} \mathrm{C}$; sample D in Table 1: $38.5^{\circ} \mathrm{C}$ ) in the same experimental conditions. Moreover, the photothermal conversion efficiency $(\eta)$ of all Ru@AuNPs were higher than this of the AuNPs $(\eta=7.3 \%-10.2 \%$ for AuNPs and $\eta=18.3 \%-33.3 \%$ for the $\mathrm{Ru} @$ AuNPs). Some of them are markedly higher than those of gold nanorods (22\%), gold nanoshells (13\%), gold nanocages $(18 \%)$ and gold nanostars $(17.9 \%)[48,49]$. In agreement with the fact that Ru2 complex had the highest TPL of the complexes studies in this work, the Ru2@AuNPs were found to have the highest temperature increase. Concurrently, the Ru3@AuNPs exhibited a minimum temperature increase since complex Ru3 had the weakest TPL of the series of complexes examined in this study. In addition, since complex Ru3 has the longest spacer, this results onto a low energy 
transfer to the AuNPs. When the Ru2@AuNPs concentration (sample D in Table 1) was fixed at $50 \mu \mathrm{g} / \mathrm{mL}$, an obvious power density dependent temperature rise was observed (Fig. S13). A temperature increase to $\sim 50{ }^{\circ} \mathrm{C}$ can be obtained with an incident laser power as low as $0.5 \mathrm{~W} / \mathrm{cm}^{2}$. This temperature increase is well above the required temperature rise for efficient cancer photothermal therapy[50]. In addition, $\Delta \mathrm{T}$ was found to increase more significantly when larger Ru@AuNPs were investigated since larger Ru@AuNPs have higher NIR absorption (Fig. S14). All in all, these results clearly show that the grafting of Ru(II) complexes with strong TPL onto AuNPs can significantly enhance the AuNPs' photothermal therapy efficiency.

The photothermal stability of the Ru2@AuNPs was further examined and benchmarked against $\mathrm{Au}$ nanorods (AuNRs) by exposing the NPs under a diode laser $(808 \mathrm{~nm})$ irradiation at the power density of $0.8 \mathrm{~W} / \mathrm{cm}^{2}$, with their near-infrared absorption spectra and the corresponding TEM images taken before and after $30 \mathrm{~min}$ of laser illumination (Fig. 5). The NIR SPR absorption of the AuNRs blue-shifted and decreased in intensity after laser exposure, indicating morphological changes to solid spheres due to the "melting effect"[51,52]. The latter was also confirmed by TEM images, showing large spherical $\mathrm{Au}$ particle formation after being exposed to laser irradiation. On the contrary, no significant change in the solution absorbance or nanostructure morphology of the Ru2@AuNPs was observed under the same experimental conditions. This clearly indicates the high photothermal stability of our Ru2@AuNPs. Moreover, the Ru2@AuNPs were able to generate heat after repetitive laser exposure (Fig. S15). The laser ON-OFF cycle was repeated five times to investigate the photothermal conversion stability of the Ru2@AuNPs. Ru2@AuNPs were irradiated with a NIR laser for $5 \mathrm{~min}$ (Laser $\mathrm{ON}$ ), followed by naturally cooling to room temperature without NIR laser irradiation over a period of $20 \mathrm{~min}$ (Laser OFF). No distinct change in the rise in temperature is observed for Ru2@AuNPs after five laser ON/OFF cycles.

In addition, to determine whether the Ru2@AuNPs can produce singlet oxygen $\left({ }^{1} \mathrm{O}_{2}\right)$ upon light irradiation, we performed experiments to detect the potential formation of ${ }^{1} \mathrm{O}_{2}$. Indeed, it is well-known that certain inert polypyridyl ruthenium complexes can produce ${ }^{1} \mathrm{O}_{2}$ upon irradiation in the UV-Vis region[40-42]. As expected, using a singlet oxygen 
sensor (DPBF)[38], we found out that the Ru2@AuNPs were producing ${ }^{1} \mathrm{O}_{2}$ upon Xenon lamp $(450 \mathrm{~nm}, 100 \mathrm{~mW})$ irradiation (Fig. S16a). Using $\left[\mathrm{Ru}(\mathrm{bpy})_{3}\right]^{2+}$ as standard $\left(\Phi_{\Delta}=\right.$ 0.81) [39], the ${ }^{1} \mathrm{O}_{2}$ generation quantum yield $\Phi_{\Delta}$ of $\mathrm{Ru} 2 @$ AuNPs was determined to be 0.20 upon $450 \mathrm{~nm}$ Xenon lamp irradiation in water. However, the irradiation of the Ru2@AuNPs with a diode laser $(808 \mathrm{~nm})$ at a power density of $0.8 \mathrm{~W} / \mathrm{cm}^{2}$ did not produce any singlet oxygen (Fig. S16b). The $808 \mathrm{~nm}$ diode laser may be not strong enough to produce ${ }^{1} \mathrm{O}_{2}$. We also considered whether the Ru2@AuNPs could produce other reactive oxidative species (ROS) than ${ }^{1} \mathrm{O}_{2}$ upon $808 \mathrm{~nm}$ laser irradiation. $\mathrm{H}_{2}$ DCF-DA (2',7'-dichlorofluorescin diacetate) has been widely used to assess the production of ROS in living cells[42]. Using this dye, we could show that ROS were not produced in HeLa cells when the Ru2@AuNPs were irradiated for 5 min with a diode laser $(808 \mathrm{~nm})$ at a power density of $0.8 \mathrm{~W} / \mathrm{cm}^{2}$ (Fig. S17a). However, when the Ru2@AuNPs $(50 \mu \mathrm{g} / \mathrm{mL})$ were irradiated for 5 min with a Xenon lamp (450 nm, 100 $\mathrm{mW}$ ), ROS was detected (Fig. S17b). These observations emphasize that the production of ROS is linked to the irradiation wavelength.

\subsection{In vitro photothermal cell ablation}

After having fully characterised the Ru@AuNPs, we examined the viability of HeLa cells treated with the Ru2@AuNPs $(45.0 \pm 1.5 \mathrm{~nm}$ size, $50 \mu \mathrm{g} / \mathrm{mL})$ without irradiation and upon 5 min laser irradiation $\left(808 \mathrm{~nm}, 0.8 \mathrm{~W} / \mathrm{cm}^{2}\right)$. The Ru2@AuNPs exhibited almost no cytotoxicity without irradiation (Fig. 6a). HeLa cells also exhibited no loss of viability after being irradiated in the absence of the nanoparticles (Fig. 6b). It means that the untreated cells remain unaffected under these laser irradiation powers (from $0.3 \mathrm{~W} / \mathrm{cm}^{2}$ to $1 \mathrm{~W} / \mathrm{cm}^{2}$ ). However, cells exposed to the Ru2@AuNPs and then irradiated, exhibited a dramatically reduced cell viability. The results indicated that the Ru2@AuNPs have a great PPT effect in living cells contrary to AuNPs, which only displayed a weak PTT effect[21-22]. Considering the red luminescence of the Ru2@AuNPs, the PPT effect of the Ru2@AuNPs was then monitored via calcein AM staining assay (Fig. S18). Viable cells were stained green with calcein AM. HeLa cells treated with the Ru2@AuNPs (50 $\mu \mathrm{g} / \mathrm{mL})$ followed by $808 \mathrm{~nm}$ laser irradiation $\left(0.8 \mathrm{~W} / \mathrm{cm}^{2}\right.$ for $\left.5 \mathrm{~min}\right)$ died (representing by the significant reduction of green fluorescence). All other groups (control, laser alone and 
Ru2@AuNPs alone) showed no observable damage to the cancer cells. In addition, to make sure that the cytotoxicity observed was not due to the Ru complexes themselves, we investigated the intrinsic cytotoxicity of the $\mathrm{Ru}$ complexes (Ru1-3) to HeLa cell lines using a MTT assay. The Ru(II) complexes also did not exhibit any obvious cytotoxicity towards the HeLa cells after $24 \mathrm{~h}$ incubation (Fig. S19).

With these results in hand, we concluded that the Ru2@AuNPs $(45.0 \pm 1.5 \mathrm{~nm}$ size, sample D) not only have the strongest heat treatment, but also have the strongest two-photon luminescence of all nanoparticles investigated in this study. Thus, the two-photon luminescent imaging-guided PTT of the Ru2@AuNPs was examined (Fig. 6c). Red two-photon luminescence was observed in the cell membrane and the cytoplasm upon light irradiation with an $808 \mathrm{~nm}$ laser $\left(0.8 \mathrm{~W} / \mathrm{cm}^{2}\right)$. Furthermore, ballooning bulges were observed (green arrow) after irradiation for 1 min and 2 min at $808 \mathrm{~nm}$. Not only did a necrotic apoptotic body area form (yellow arrow) after a 5 min irradiation, but the viability of cells around the circular NIR-irradiated region was also compromised. These results demonstrate the excellent potential of the Ru2@AuNPs as photothermal therapy agents against HeLa cancer cells.

\subsection{Cell uptake analysis}

In order to understand in more detail the mode of action of the Ru2@AuNPs, the cellular uptake and localization of the Ru2@AuNPs were examined in HeLa cells. Flow cytometry was used to obtain qualitative data regarding Ru2@AuNPs uptake into HeLa cells. The luminescence intensity of the cell population increased significantly after incubating with the Ru2@AuNPs (Fig. 7a). Quantitative analysis (ICP-MS) provided absolute values for the cellular uptake of the Ru2@AuNPs (Fig. 7b). The results revealed that the Ru2@AuNPs mainly go to the cytoplasm and to a much smaller extend to the nucleus. The subcellular localization of the Ru2@AuNPs was further confirmed via confocal fluorescence microscopy (Fig. 7c). The red two-photon luminescence mainly accumulated in the cytoplasm. TEM is a convincing method for observing the pathways through which the Ru2@AuNPs enter cancer cells. This tecnhnique supports an endocytosis mechanism for the uptake of the Ru2@AuNPs and shows that the Ru2@AuNPs form endosomes in cells (Fig. 7d). 


\subsection{Photothermal therapy in vivo}

We further attempted to study the in vivo photothermal therapy efficacy of our Ru2@AuNPs. At this stage, it should be pointed out that the preferred route of photothermal conversion agents (PTCAs) administration in photothermal cancer therapy is intratumoral injection instead of intravenous injection[53-56]. Nie et al. recently reported that active molecular targeting of the tumor microenvironments (e.g., fibroblasts, macrophages, and vasculatures) did not significantly influence the tumor nanoparticle uptake when the gold nanoparticels were administered via intravenous injection[57]. Because of this, we opted in the present study for intratumoral injection to assesss the in vivo PPT potential of our Ru2@AuNPs.

In our experiment setting, when the tumor volume reached approximately $120 \mathrm{~mm}^{3}$, the nude mice were randomly allocated into six groups ( 8 mice per group) before the experiments (day 0). For the treatment group (Ru2@AuNPs + laser), after the injection of the Ru2@AuNPs (200 $\mu \mathrm{g} / 20 \mathrm{~g}$ body weight), the HeLa tumors were irradiated with a diode laser $(808 \mathrm{~nm})$ at $0.8 \mathrm{~W} / \mathrm{cm}^{2}$ for $5 \mathrm{~min}$. We observed that the HeLa tumors were effectively ablated and round. Black scars were observed in the original sites, and the tumors were shrinking gradually or even disappeared individually after 10 days of treatment (Fig. 8). However, for the other five control groups of mice which were treated with 1) the Ru2@AuNPs alone; 2) a physiological saline solution followed by laser irradiation; 3) a physiological saline solution alone; 4) the AuNPs followed by laser irradiation; 5) Ru2 followed by laser irradiation, the tumors in these groups still grew quickly (Fig. S20 and Fig. S21). Histological examination was performed after the photothermal therapy treatment. As expected, in the mice treated with the Ru2@AuNPs followed by laser irradiation, the tumor tissues were necrotic, exhibiting pyknosis, karyolysis, and degradation. On the contrary, the tumor tissues of the four other mouse groups exhibited a normal-organised cellular structure (Fig. S20b).

To determine whether the treatments induced toxicity, we monitored the body weight of the mice (Fig. S22) and the histology of organs including the liver, kidney, spleen, heart, lung, brain, intestine and ovary (Fig. S23). The the body weight of the mice treated with the Ru2@AuNPs under a diode laser $(808 \mathrm{~nm})$ irradiation at the power density of 
$0.8 \mathrm{~W} / \mathrm{cm}^{2}$ (group 2) was no different to that of the controls. No body weight loss and other serious toxic effects were observed. In addition, histological analysis did not reveal any serious irreversible pathological alterations or injuries in the organs of mice of all five groups. This strongly suggests that the Ru2@AuNPs medicated photothermal ablation is not inducing any toxicity. All results clearly indicate that the Ru2@AuNPs act as powerful photothermal agents in vivo.

\section{Conclusion}

In summary, in this article, we present a successful strategy for efficiently improving the photothermal therapy efficiency of gold nanospheres by grafting two-photon luminescent $\mathrm{Ru}(\mathrm{II})$ complex antennas. The best dual functional nanoparticles, namely the Ru2@AuNPs, exhibited both strong two-photon luminescence and high photothermal therapy efficiency $\left(\Delta \mathrm{T}=38.5{ }^{\circ} \mathrm{C}, \eta=33.3 \%\right)$. The Ru2@AuNPs were used for two-photon luminescent imaging-guided PTT in real time in living cells. Very importantly, the photothermal therapy potential of the Ru2@AuNPs was further demonstrated on mice. These in vivo experiments indicated that the use of Ru2@AuNPs as PTT agents offer excellent tumor ablation therapeutic efficacy under a diode laser (808 $\mathrm{nm}$ ) irradiation at the power density of $0.8 \mathrm{~W} / \mathrm{cm}^{2}$ for $5 \mathrm{~min}$. The laser power used in the present study was even lower than those of some recent reports[58-64]. All in all, our study highlights the potential of using $\mathrm{Ru}(\mathrm{II})$-functionalized AuNPs for cancer theranostic applications.

\section{Conflict of interest}

No financial conflict of interest was reported by the authors of this paper.

\section{Acknowledgments}

This work was supported by the 973 program (Nos. 2014CB845604 and 2015CB856301), the National Science Foundation of China (Nos. 21172273, 21171177, and 21471164), Program for Changjiang Scholars and Innovative Research Team in 
University of China (No. IRT1298), the Swiss National Science Foundation (SNSF Professorships PP00P2_133568 and PP00P2_157545) and the University of Zurich.

\section{Appendix A. Supplementary data}

Supplementary data related to this article can be found at http://dx.doi.org/. 


\section{Scheme and Figure Captions}

\begin{tabular}{|c|c|}
\hline Table 1 & Summary of the characteristics of the AuNPs and of the Ru@AuNPs. \\
\hline Fig. 1 & $\begin{array}{l}\text { Schematic illustration of the three different Ru(II) complexes (Ru1, } \\
\text { Ru2, Ru3) grafted onto gold nanoparticles (Ru1@AuNPs, } \\
\text { Ru2@AuNPs, Ru3@AuNPs) of the change of two-photon } \\
\text { luminescence and of the photothermal efficiency of the Ru@AuNPs. } \\
\text { GM is the unit of two-photon absorption cross-section } \delta(1 \mathrm{GM}=1 \times \\
\left.10^{-50} \mathrm{~cm}^{4} \cdot \mathrm{s}^{-1} \cdot \text { photon }^{-1}\right) \text {. }\end{array}$ \\
\hline Fig. 2 & $\begin{array}{l}\text { (a, b) TEM and HRTEM images of the synthesized Ru2@AuNPs } \\
\text { (sample D, } 50 \mu \mathrm{g} / \mathrm{mL} \text { ). (c) EDX spectrum of the Ru2@AuNPs. (d) } \\
\text { XPS spectra of the Ru2@AuNPs ( } \mathrm{C}_{1 \mathrm{~s}} \text { and Ru3d). }\end{array}$ \\
\hline Fig. 3 & $\begin{array}{l}\text { Two-photon absorption cross-section of the Ru(II) complexes and of } \\
\text { the Ru@AuNPs obtained using excitation wavelengths from } 700 \text { to } \\
1050 \mathrm{~nm} \text {. }\end{array}$ \\
\hline Fig. 4 & $\begin{array}{l}\text { a) Photothermal images of the gold nanoparticle solutions (sample D } \\
\text { in Table 1) at the same concentration }(100 \mu \mathrm{L}, 50 \mu \mathrm{g} / \mathrm{mL}) \text { and } \\
\text { irradiation time ( } 0-5 \text { min). The power of the } 808 \mathrm{~nm} \text { laser was } 0.8 \\
\text { W/cm² (A: Ru1@AuNPs; B: Ru2@AuNPs; C: Ru3@AuNPs; D: } \\
\left.\text { AuNPs; E: Ru1; F: Ru2; G: Ru3; } \mathrm{H}: \mathrm{H}_{2} \mathrm{O}\right) \text {. b) The temperature change } \\
\text { of the Ru@Au nanoparticles as a function of irradiation time; } \mathrm{H}_{2} \mathrm{O} \text { and } \\
\text { pure gold nanoparticles as controls. }\end{array}$ \\
\hline Fig. 5 & $\begin{array}{l}\text { UV-vis-NIR absorption spectra of the Ru2@AuNPs (a) and of the } \\
\text { AuNRs (b) in the aqueous solution, and TEM images of the } \\
\text { Ru2@AuNPs (c) and of the AuNRs ( d) morphology before and after } \\
808 \mathrm{~nm} \text { laser irradiation }\left(0.8 \mathrm{~W} / \mathrm{cm}^{2}, 30 \mathrm{~min}\right) \text {. }\end{array}$ \\
\hline Fig. 6 & $\begin{array}{l}\text { a) Cell viability of } \mathrm{HeLa} \text { cancer cells after treatment with different } \\
\text { concentration of the Ru2@AuNPs ( } 45.0 \pm 1.5 \mathrm{~nm} \text { size) for } 24 \mathrm{~h} \text { under } \\
\text { no laser irradiation. b) Viability of HeLa cells after Ru2@AuNPs }\end{array}$ \\
\hline
\end{tabular}




\begin{tabular}{|c|c|}
\hline & $\begin{array}{l}(45.0 \pm 1.5 \mathrm{~nm} \text { size, } 50 \mu \mathrm{g} / \mathrm{mL}) \text { induced photothermal therapy upon } 808 \\
\mathrm{~nm} \text { irradiation at different laser power densities. The Ru2 complex } \\
\text { was included as a control. c) Real-time two-photon luminescence } \\
\text { images of the Ru2@AuNPs }(45.0 \pm 1.5 \mathrm{~nm} \text { size, } 50 \mu \mathrm{g} / \mathrm{mL}) \text { in HeLa } \\
\text { cells measured by laser scanning confocal microscope after different } \\
\left.\text { irradiation times ( } 808 \mathrm{~nm}, 0.8 \mathrm{~W} / \mathrm{cm}^{2}, 0-5 \mathrm{~min}\right) \text {. White circle indicates } \\
\text { the laser spot. Membrane blebbing (green arrow) and apoptotic bodied } \\
\text { (yellow arrow) were observed. }\end{array}$ \\
\hline Fig. 7 & $\begin{array}{l}\text { Cellular uptake analysis of the Ru2@AuNPs by a) flow cytometry b) } \\
\text { ICP-MS; c) Confocal fluorescence microscopy (from left to right: } \\
\text { bright field, Ru@AuNPs' two-photon luminescence, Hoechst } 33258 \\
\text { luminescence and overlay images); d) TEM images show that the } \\
\text { Ru2@AuNPs form an endosome (white \#) after entering the cell; } \\
\text { HeLa cells incubated with the Ru2@AuNPs }\left(50 \mu \mathrm{g} / \mathrm{mL} \text { ) at } 37{ }^{\circ} \mathrm{C} \text { for } 1\right. \\
\text { h. }\end{array}$ \\
\hline Fig & $\begin{array}{l}\text { a) Representative photographs of HeLa tumors in mice in the presence } \\
\text { of the Ru2@AuNPs without/with } 808 \mathrm{~nm} \text { laser treatments }\left(0.8 \mathrm{~W} / \mathrm{cm}^{2} \text {, }\right. \\
5 \mathrm{~min}) \text {. b) Histological examination of tumors without/with laser } \\
\text { treatments on day 10. c) The tumor growth curves for the two mice } \\
\text { groups after treatment. The dose was } 200 \mu \mathrm{g} \text { nanoparticles per } 20 \mathrm{~g} \\
\text { mouse body weight. Tumor volumes were normalized to their initial } \\
\text { sizes. Error bars represent the standard deviation of } 8 \text { mice per group. } \\
*=\mathrm{p}<0.01 \text {, compared with the Ru2@AuNPs group. }\end{array}$ \\
\hline
\end{tabular}




\section{References}

[1] Dreaden EC, Mackey MA, Huang XH, Kang B, El-Sayed MA. Beating cancer in multiple ways using nanogold. Chem. Soc. Rev. 2011;40:3391-3404.

[2] Wang ST, Chen KJ, Wu TH, Wang H, Lin WY, Ohashi M, Chiou PY, Tseng HR, Photothermal effects of supramolecularly assembled gold nanoparticles for the targeted treatment of cancer cells. Angew. Chem. Int. Ed. 2010;49:3777-3781.

[3] Qina ZP, Bischof JC. Thermophysical and biological responses of gold nanoparticle laser heating. Chem. Soc. Rev. 2012;41:1191-1217.

[4] Yang K, Feng LZ, Shi XZ, Liu Z, Nano-graphene in biomedicine: theranostic applications. Chem. Soc. Rev. 2013;42:530-547.

[5] Zha ZB, Yue XL, Ren QS, Dai ZF. Uniform polypyrrole nanoparticles with high photothermal conversion efficiency for photothermal ablation of cancer cells. Adv. Mater. 2013;25: 777-782.

[6] Huang XQ, Tang SH, Liu BJ, Ren B, Zheng NF. Enhancing the photothermal stability of plasmonic metal nanoplates by a core-shell architecture. Adv. Mater. 2011;23:3420-3425.

[7] Yuan H, Fales AM, Vo-Dinh T. TAT peptide-functionalized gold nanostars: enhanced intracellular delivery and efficient NIR photothermal therapy using ultralow irradiance. J. Am. Chem. Soc. 2012;134:11358-11361.

[8] Robinson JT; Hong GS, Liang YY, Zhang B, Yaghi OK, Dai HJ. In vivo fluorescence imaging in the second near-infrared window with long circulating carbon nanotubes capable of ultrahigh tumor uptake. J. Am. Chem. Soc. 2012; 134:10664-10669.

[9] Kalluru P, Vankayala R, Chiang CS, Hwang KC. Photosensitization of singlet oxygen and in vivo photodynamic therapeutic effects mediated by PEGylated $\mathrm{W}(18) \mathrm{O}(49)$ nanowires. Angew. Chem. Int. Ed. 2013;52:12332-12336.

[10] Spence GT, Hartland GV, Smith BD. Activated photothermal heating using croconaine dyes. Chem. Sci. 2013;4:4240-4244.

[11] Li H, Tan LL, Jia P, Li QL, Sun YL, Zhang J, Ning YQ, Yu JH, Yang YW, Near-infrared light-responsive supramolecular nanovalve based on mesoporous silica-coated gold nanorods.Chem. Sci. 2014, 5, 2804-4434.

[12] Murphy CJ, Gole AM, Stone JW, Sisco PN, Alkilany AM, Goldsmith EC, Baxter 
SC. Gold nanoparticles in biology: beyond toxicity to cellular imaging. Acc. Chem. Res. 2008;41:1721-1730.

[13] Biju V, Chemical modifications and bioconjugate reactions of nanomaterials for sensing, imaging, drug delivery and therapy. Chem. Soc. Rev. 2014;43:744-764.

[14] Wang ZD, Tang LH, Tan LH, Li JH, Lu Y. Discovery of the DNA "genetic code" for abiological gold nanoparticle morphologies. Angew. Chem. Int. Ed. 2012;51:9078 -9082 .

[15] Kuo WS, Chang CN, Chang YT, Yang MH, Chien YH, Chen SJ, Yeh CS. Gold nanorods in photodynamic therapy, as hyperthermia agents, and in near-infrared optical imaging. Angew. Chem. Int. Ed. 2010;49:2711-2715.

[16] Moon GD, Choi SW, Cai X, Li W, Cho EC, Jeong U, Wang LV, Xia Y. A new theranostic system based on gold nanocages and phase-change materials with unique features for photoacoustic imaging and controlled release. J. Am. Chem. Soc. 2011;133:4762-4765.

[17] Skrabalak SE, Chen J, Sun Y, Lu X, Au L, Cobley CM, Xia Y. Gold nanocages: synthesis, properties, and applications. Acc. Chem. Res. 2008;4:1587-1595.

[18] Chen J, Wang D, Xi J, Au L, Siekkinen A, Warsen A, Li ZY, Zhang H, Xia Y, Li X. Immuno gold nanocages with tailored optical properties for targeted photothermal destruction of cancer cells. Nano Lett. 2007;7:1318-1322.

[19] Giljohann DA, Seferos DS, Daniel WL, Massich MD, Patel PC, Mirkin CA, Gold nanoparticles for biology and medicine. Angew. Chem. Int. Ed. 2010;49:3280-3294.

[20] Jans H, Huo Q. Gold nanoparticle-enabled biological and chemical detection and analysis. Chem. Soc. Rev. 2012;41:2849-2866.

[21] Khlebtsov B, Zharov V, Melnikov A, et al. Optical amplification of photothermal therapy with gold nanoparticles and nanoclusters. Nanotechnology, 2006;17:5167.

[22] Jin YD, Gao XH. Spectrally tunable leakage-free gold nanocontainers. J. Am. Chem. Soc. 2009; 131:17774-17776.

[23] Lapotko D, Lukianova E, Potapnev M, Aleinikova O, Oraevsky A. Method of laser activated nano-thermolysis for elimination of tumor cells. Cancer Lett. 2006;239:36-45. 
[24] You J, Zhang R, Zhang G, Zhong M, Liu Y, Van Pelt CS, Liang D, Wei W, Sood AK, Li C. Photothermal-chemotherapy with doxorubicin-loaded hollow gold nanospheres: A platform for near-infrared light-trigged drug release. J Control Release 2012;158:319-328.

[25] Gasser G, Ott I, Metzler-Nolte N. Organometallic anticancer compounds. J. Med. Chem. 2011;54:3-25.

[26] Zhang PY, Pei, LM, Chen Y, Chao H, et al. A dinuclear ruthenium(II) complex as a one- and two-photon luminescent probe for biological $\mathrm{Cu}^{2+}$ detection. Chem. Eur. J. 2013;19:15494-15503.

[27] Zhang PY, Wang JQ, Huang HY, Chao H, et al. RuNH2@AuNPs as two-photon luminescent probes for thiols in living cells and tissues. Biomaterials 2014;35:9003-9011.

[28] Balzani V, Bergamini G, Marchioni F, et al. Ru (II)-bipyridine complexes in supramolecular systems, devices and machines. Coord. Chem. Rev. 2006;250:1254-1266.

[29] Mayer CR, Dumas E, Miomandre F, Meallet-Renault R, et al. Polypyridyl ruthenium complexes as coating agent for the formation of gold and silver nanocomposites in different media. Preliminary luminescence and electrochemical studies. New J. Chem. 2006, 30, 1628-1637.

[30] Mayer CR, Dumas E, Sécheresse FJ. 1,10-Phenanthroline and 1,10-phenanthroline -terminated ruthenium(II) complex as efficient capping agents to stabilize gold nanoparticles: application for reversible aqueous-organic phase transfer processes. Colloid. Interf. Sci. 2008;328:452-457.

[31] Elmes RBP, Orange KN, Cloonan SM, Williams DC, Gunnlaugsson T. Luminescent ruthenium(II) polypyridyl functionalized gold nanoparticles; their DNA binding abilities and application as cellular imaging agents. J. Am. Chem. Soc. 2011;133:15862-15865.

[32] Yu YQ, Zhou M, Cui H. Synthesis and electrochemiluminescence of bis (2, 2'-bipyridine)(5-amino-1, 10-phenanthroline) ruthenium (II)-functionalized gold nanoparticles. J. Mater. Chem. 2011;21:12622-12625.

[33] Rogers NJ, Claire S, Harris RM, et al. High coating of Ru (II) complexes on gold 
nanoparticles for single particle luminescence imaging in cells. Chem. Commun. 2014;50: 617-619.

[34] Chao H, Li RH, Jiang CW, et al. Mono-, di- and tetra-nuclear ruthenium(II) complexes containing 2,2-p-phenylenebis(imidazo[4,5-f]phenanthroline): synthesis, characterization and third-order non-linear optical properties. J. Chem. Soc. Dalton Trans. 2001;1920-1926.

[35] $\mathrm{Xu} \mathrm{C}$, Webb W. W. Measurement of two-photon excitation cross sections of molecular fluorophores with data from 690 to $1050 \mathrm{~nm}$. J. Opt. Soc. Am. B $1996 ; 13: 481-491$.

[36] Au L, Zhang Q, Cobley CM, Xia YN, et al. Quantifying the cellular uptake of antibody-conjugated $\mathrm{Au}$ nanocages by two-photon microscopy and inductively coupled plasma mass spectrometry. ACS Nano 2010;4:35-42.

[37] Tian Q, Jiang F, Zou R, Hu J, et al. Hydrophilic Cu9 55 nanocrystals: a photothermal agent with a $25.7 \%$ heat conversion efficiency for photothermal ablation of cancer cells in vivo. ACS Nano 2011;5:9761-9771.

[38] Yu HJ, Huang SM, Li LY, et al. Synthesis, DNA-binding and photocleavage studies of ruthenium complexes $[\mathrm{Ru}(\mathrm{bpy}) 2($ mitatp) $] 2+$ and $[\mathrm{Ru}(\mathrm{bpy}) 2$ (nitatp) $] 2+$. J. Inorg. Biochem. 2009;103:881-890.

[39] Abdel-Shafi AA, Beer PD, Mortimer RJ, Wilkinson F. J. Phys. Chem. A 2000;104:192-202.

[40] Frei A, Rubbiani R, Tubafard S, Blacque O, Anstaett P, Felgenträger A, Maisch T, Spiccia L, Gasser G. Synthesis, characterization, and biological evaluation of new $\mathrm{Ru}(\mathrm{II})$ polypyridyl photosensitizers for photodynamic therapy. J. Med. Chem. 2014;57:7280-7292.

[41] Mari C, Pierroz V, Rubbiani R, Patra M, Hess J, Spingler B, Oehninger L, Schur J, Ott I, Salassa L, Ferrari S, Gasser G. DNA intercalating Ru(II) polypyridyl complexes as effective photosensitizers in photodynamic therapy. Chem. Eur. J. 2014;20:14421-14436.

[42] Pierroz V, Joshi T, Leonidova A, Mari C, Schur J, Ott I, Spiccia L, Ferrari S, Gasser G. Molecular and cellular characterization of the biological effects of ruthenium(II) complexes incorporating 2-pyridyl-2-pyrimidine-4-carboxylic acid. J. Am. Chem. 
Soc. 2012, 134, 20376-20387.

[43] Yu LF, Chen MCW, Cheung KC. Droplet-based microfluidic system for multicellular tumor spheroid formation and anticancer drug testing. Lab Chip 2010; 10:2424-2432.

[44] Gobin AM, Lee MH, Halas NJ, James WD, Drezek RA, West JL. Near-infrared resonant nanoshells for combined optical imaging and photothermal cancer therapy. Nano Lett. 2007;7:1929-1934.

[45] Park JH, von Maltzahn G, Xu MJ, Fogal V, Kotamraju VR, Ruoslahti E, Bhatia SN, Sailor MJ. Cooperative nanomaterial system to sensitize, target, and treat tumors. Proc. Natl. Acad. Sci. USA 2010;107: 981-986.

[46] Moriggi L, Cannizzo C, Dumas E, Mayer CR, Ulianov A, Helm L. J. Am. Chem. Soc. Gold nanoparticles functionalized with gadolinium chelates as high-relaxivity MRI contrast agents. 2009;131:10828-10829.

[47] Brown SD, Nativo P, Smith JA, Stirling D, Edwards PR, Venugopal B, Flint DJ, Plumb JA, Graham D, Wheate NJ. Gold nanoparticles for the improved anticancer drug delivery of the active component of oxaliplatin. J. Am. Chem. Soc. 2010;132: $4678-4684$.

[48] Hessel CM, Pattani VP, Rasch M, Panthani MG, Koo B, Tunnell JW, Korgel BA. Copper selenide nanocrystals for photothermal therapy. Nano Lett. 2011;11:2560-2566.

[49] Huang P, Lin J, Li WW, Rong PF, et al. Biodegradable gold nanovesicles with an ultrastrong plasmonic coupling effect for photoacoustic imaging and photothermal therapy. Angew. Chem. Int. Ed. 2013;52:13958-13964.

[50] Tian QW, Hu JQ, Zhu YH, Zou RJ, Chen ZG, et al. Sub-10 nm Fe $\mathrm{O}_{4} @ \mathrm{Cu}_{(2-\mathrm{x})} \mathrm{S}$ core-shell nanoparticles for dual-modal imaging and photothermal therapy. J. Am. Chem. Soc. 2013;135: 8571-8577.

[51] Ding XG, Liow $\mathrm{CH}$, Zhang MX, et al. Surface plasmon resonance enhanced light absorption and photothermal therapy in the second near-infrared window. J. Am. Chem. Soc. 2014;136:15684-15693.

[52] Wang YC, Black KCL, Luehmann H, Xia YN, et al. Comparison study of gold nanohexapods, nanorods, and nanocages for photothermal cancer treatment. ACS 
Nano, 2013;7:2068-2077.

[53] Zhou M, Zhang, R, Huang M, Lu W, et al. A chelator-free multifunctional $\left[{ }^{64} \mathrm{Cu}\right] \mathrm{CuS}$ nanoparticle platform for simultaneous micro-PET/CT imaging and photothermal ablation therapy. J. Am. Chem. Soc. 2010;132:15351-15358.

[54] Xie H, Goins B, Bao A, Wang ZJ, Phillips WT. Effect of intratumoral administration on biodistribution of ${ }^{64} \mathrm{Cu}$-labeled nanoshells. Int. J. Nanomed. 2012;7:2227-2238.

[55] Albanese A, Tang PS, Chan WC. The effect of nanoparticle size, shape, and surface chemistry on biological systems. Annu. Rev. Biomed. Eng. 2012;14:1-16.

[56] De Jong, WH, Hagens WI, Krystek P, Burger MC, Sips AJ, Geertsma RE. Particle size-dependent organ distribution of gold nanoparticles after intravenous administration. Biomaterials 2008, 29, 1912-1919.

[57] Huang XH, Peng XH, Wang YQ, Wang YX, ElSayed MA, Nie SM. A Reexamination of Active and Passive Tumor Targeting by Using Rod-Shaped Gold Nanocrystals and Covalently Conjugated Peptide Ligands. ACS Nano 2010;4:5887-5896.

[58] Lin J, Wang S, Huang P, Nie, ZH, et al. Photosensitizer-loaded gold vesicles with strong plasmonic coupling effect for imaging-guided photothermal/photodynamic therapy. ACS Nano 2013;7:5320-5329.

[59] Huang, XH, El-Sayed IH, Qian W, El-Sayed MA. Cancer cell imaging and photothermal therapy in the near-infrared region by using gold nanorods. J. Am. Chem. Soc. 2006;128:2115-2120.

[60] Ke H, Wang J, Dai ZF, Jin Y, et al. Gold-nanoshelled microcapsules: a theranostic agent for ultrasound contrast imaging and photothermal therapy. Angew. Chem. Int. Ed. 2011;50:3017-3021.

[61] Li W, Rong P, Yang K, Huang P, Sun K, Chen X. Semimetal nanomaterials of antimony as highly efficient agent for photoacoustic imaging and photothermal therapy. Biomaterials 2015;45:8-26.

[62] Li B, Ye K, Zhang Y, Qin J, et al. Photothermal Theragnosis Synergistic Therapy Based on Bimetal Sulphide Nanocrystals Rather Than Nanocomposites. Adv Mater. 2015;27:1339-1345.

[63] Liu J, Zheng X, Yan L, Zhou L, et al. Bismuth sulfide nanorods as a precision 
nanomedicine for in vivo multimodal imaging-guided photothermal therapy of tumor. ACS Nano 2015;9:696-707.

[64] Jung HS, Han J, Lee JH, Lee JH, et al. Enhanced NIR Radiation-Triggered Hyperthermia by Mitochondrial Targeting. J. Am. Chem. Soc. 2015;DOI: $10.1021 / \mathrm{ja} 5122809$. 
Table 1

Summary of the characteristics of the AuNPs and of the Ru@AuNPs.

\begin{tabular}{|c|c|c|c|c|c|c|c|c|}
\hline \multicolumn{2}{|c|}{ Ru@AuNPs } & \multirow{2}{*}{$\begin{array}{c}\text { Size/nm } \\
4.0 \pm 0.3\end{array}$} & \multirow{2}{*}{$\frac{\mathrm{N}(\mathrm{Ru}) / \mathrm{AuNPs}}{112}$} & \multirow{2}{*}{$\begin{array}{c}\text { Zeta potential } \\
(\mathrm{mV})\end{array}$} & \multirow{2}{*}{ 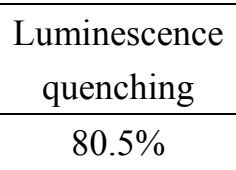 } & \multirow{2}{*}{$\begin{array}{c}\text { TPA }(\delta / G M) \\
\text { at } 808 \mathrm{~nm} \\
18.0\end{array}$} & \multirow{2}{*}{$\frac{\Delta \mathrm{T} /{ }^{\circ} \mathrm{C}}{22.4}$} & \multirow{2}{*}{$\frac{\eta}{19.2 \%}$} \\
\hline Ru1@AuNPs & $\mathrm{A}$ & & & & & & & \\
\hline & $\mathrm{B}$ & $13.0 \pm 1.0$ & 336 & +16.6 & $92.3 \%$ & 12.0 & 26.7 & $21.7 \%$ \\
\hline & $\mathrm{C}$ & $32.0 \pm 1.5$ & 470 & +20.7 & $94.7 \%$ & 9.9 & 29.9 & $23.8 \%$ \\
\hline & $\mathrm{D}$ & $42.0 \pm 2.0$ & 523 & +23.9 & $96.5 \%$ & 7.8 & 32.4 & $25.9 \%$ \\
\hline \multirow[t]{4}{*}{ Ru2@AuNPs } & A & $5.4 \pm 0.5$ & 180 & +15.6 & $22.6 \%$ & 308 & 23.7 & $19.9 \%$ \\
\hline & $\mathrm{B}$ & $14.0 \pm 0.7$ & 507 & +21.8 & $40.8 \%$ & 241 & 30.2 & $25.5 \%$ \\
\hline & $\mathrm{C}$ & $34.0 \pm 1.5$ & 715 & +24.9 & $55.2 \%$ & 209 & 35.4 & $31.4 \%$ \\
\hline & $\mathrm{D}$ & $45.0 \pm 1.5$ & 810 & +26.4 & $57.9 \%$ & 187 & 38.5 & $33.3 \%$ \\
\hline \multirow[t]{4}{*}{ Ru3@AuNPs } & A & $5.2 \pm 0.5$ & 205 & +16.0 & $12.7 \%$ & 154 & 19.4 & $18.3 \%$ \\
\hline & $\mathrm{B}$ & $16.0 \pm 1.0$ & 624 & +22.2 & $33.6 \%$ & 123 & 21.7 & $19.1 \%$ \\
\hline & $\mathrm{C}$ & $35.0 \pm 0.8$ & 843 & +26.2 & $38.8 \%$ & 110 & 26.5 & $21.6 \%$ \\
\hline & $\mathrm{D}$ & $47.0 \pm 2.0$ & 890 & +27.0 & $40.5 \%$ & 105 & 29.1 & $23.5 \%$ \\
\hline \multirow[t]{4}{*}{ AuNPs } & $\mathrm{A}$ & $3.5 \pm 0.2$ & - & -26.6 & - & - & 8.6 & $7.3 \%$ \\
\hline & B & $10.0 \pm 0.5$ & - & -26.8 & - & - & 9.4 & $8.5 \%$ \\
\hline & $\mathrm{C}$ & $27.0 \pm 1.0$ & - & -27.6 & - & - & 11.3 & $9.6 \%$ \\
\hline & $\mathrm{D}$ & $40.0 \pm 1.5$ & - & -28.5 & - & - & 12.1 & $10.2 \%$ \\
\hline
\end{tabular}




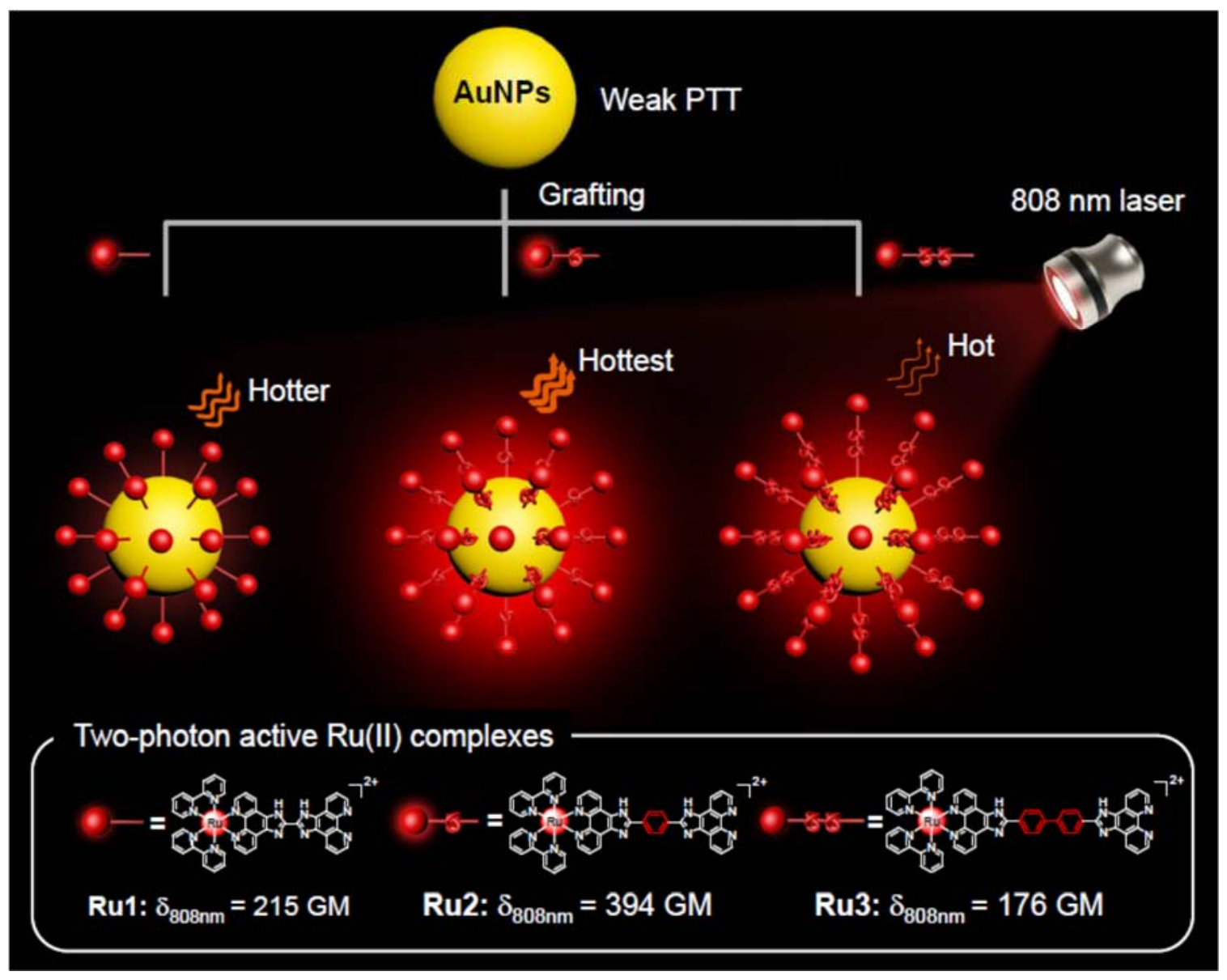

Fig. 1. Schematic illustration of the three different $R$ (II) complexes (Ru1, Ru2, Ru3) grafted onto gold nanoparticles (Ru1@AuNPs, Ru2@AuNPs, Ru3@AuNPs) of the change of two-photon luminescence and of the photothermal efficiency of the $\mathrm{Ru} @$ AuNPs. GM is the unit of two-photon absorption cross-section $\delta\left(1 \mathrm{GM}=1 \times 10^{-50}\right.$ $\mathrm{cm}^{4} \cdot \mathrm{s}^{-1} \cdot$ photon $\left.^{-1}\right)$. 


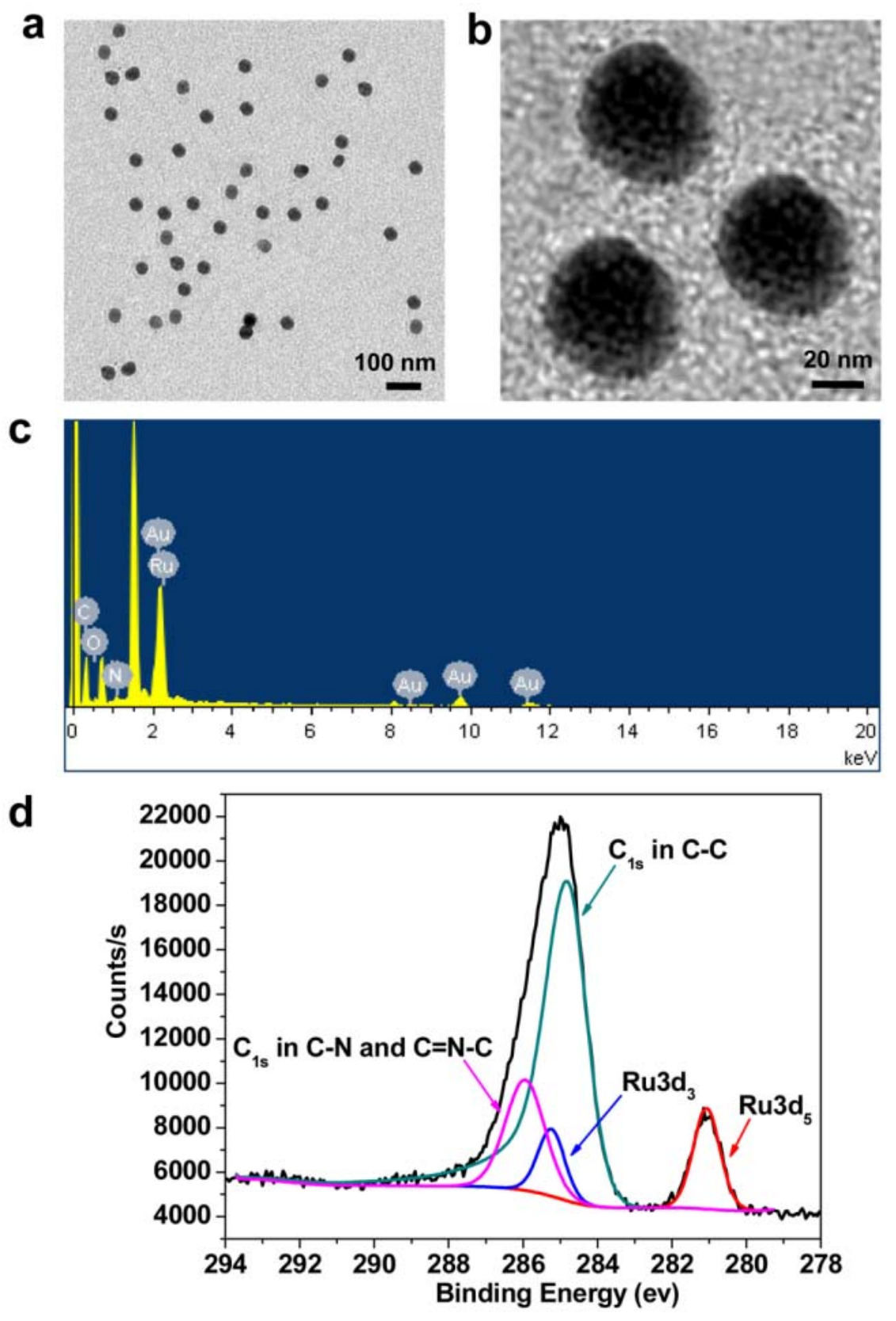

Fig. 2. (a, b) TEM and HRTEM images of the synthesized Ru2@AuNPs (sample D, 50 $\mu \mathrm{g} / \mathrm{mL}$ ). (c) EDX spectrum of the Ru2@AuNPs. (d) XPS spectra of the Ru2@AuNPs $\left(\mathrm{C}_{1 \mathrm{~s}}\right.$ and $\left.\mathrm{Ru} \mathrm{u}_{3}\right)$. 

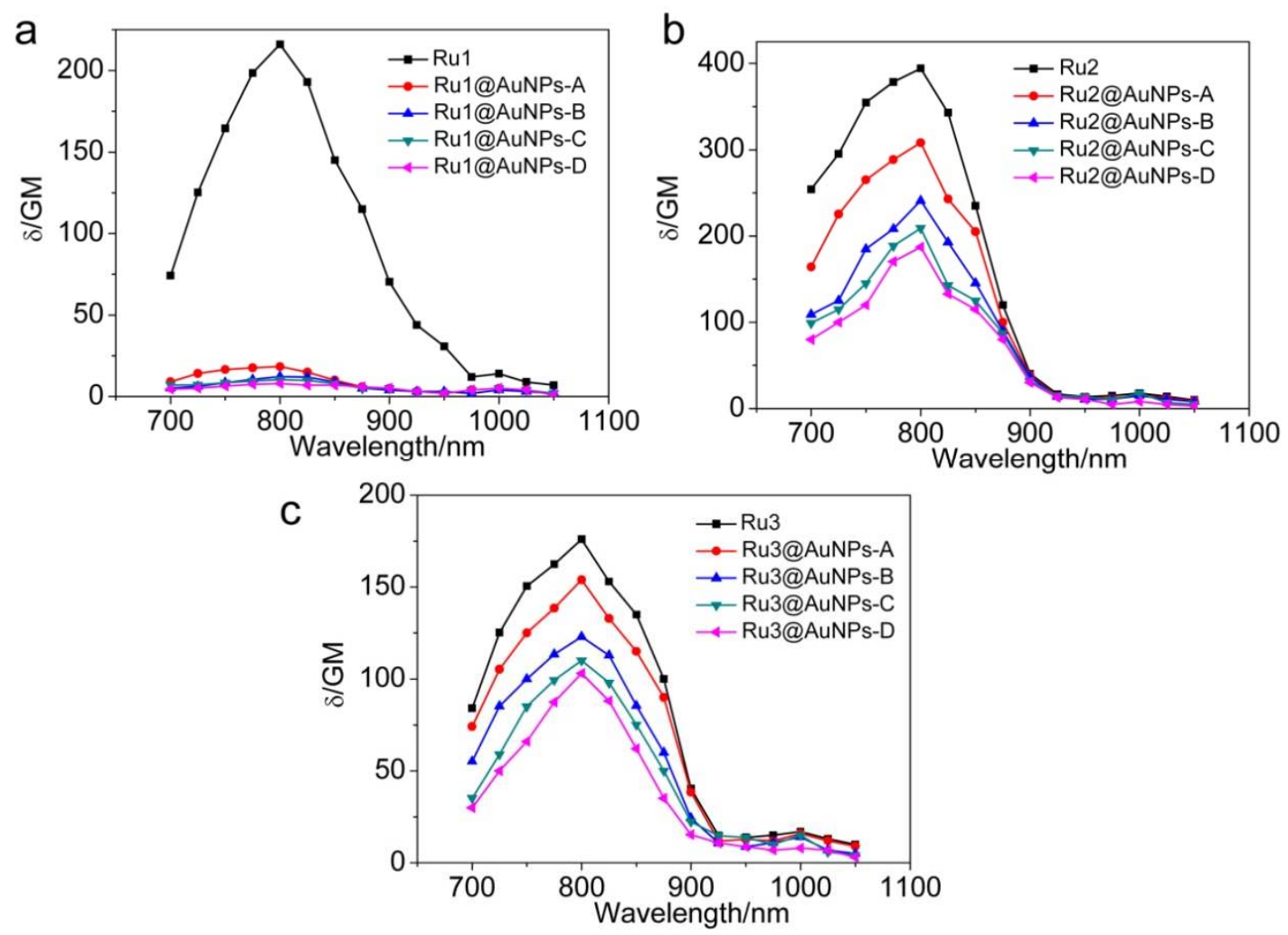

Fig. 3. Two-photon absorption cross-section of the $\mathrm{Ru}(\mathrm{II})$ complexes and of the Ru@AuNPs obtained using excitation wavelengths from 700 to $1050 \mathrm{~nm}$. 


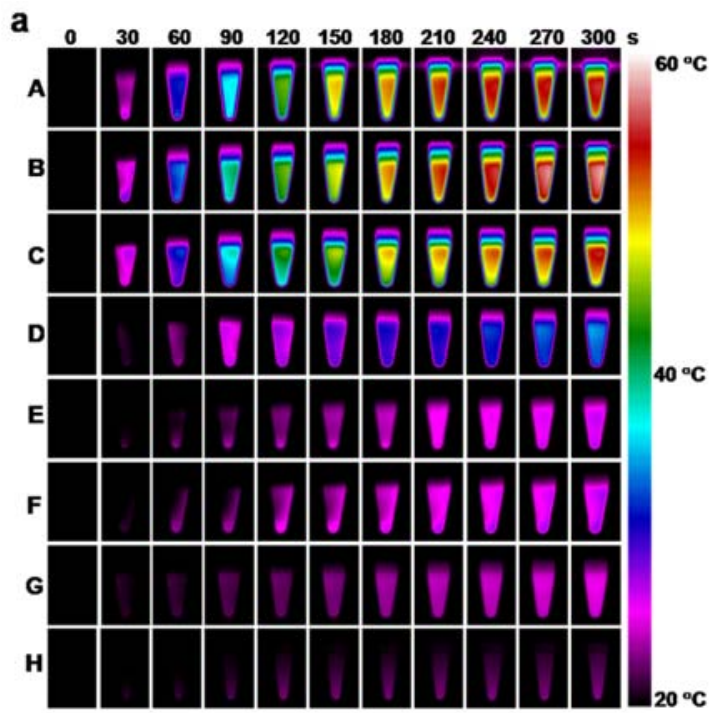

b

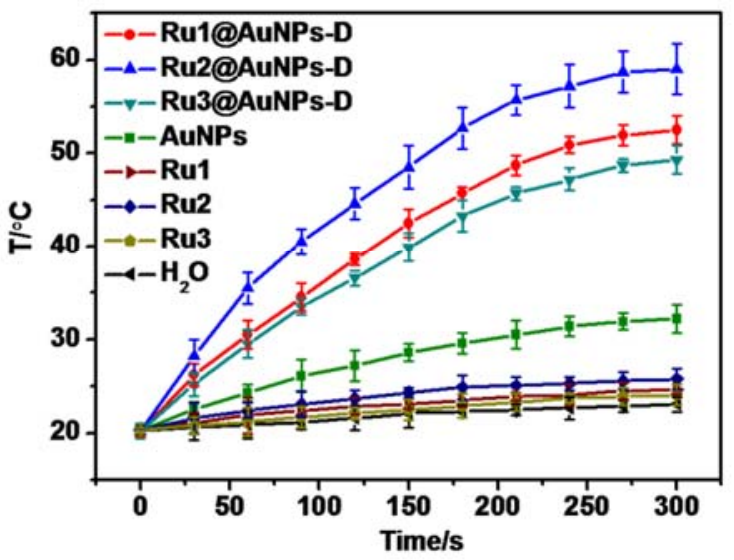

Fig. 4. a) Photothermal images of the gold nanoparticle solutions (sample D in Table 1) at the same concentration $(100 \mu \mathrm{L}, 50 \mu \mathrm{g} / \mathrm{mL})$ and irradiation time $(0-5 \mathrm{~min})$. The power of the 808 nm laser was 0.8 W/cm² (A: Ru1@AuNPs; B: Ru2@AuNPs; C: Ru3@AuNPs; D: AuNPs; E: Ru1; F: Ru2; G: Ru3; H: $\mathrm{H}_{2} \mathrm{O}$ ). b) The temperature change of the $\mathrm{Ru} @ \mathrm{Au}$ nanoparticles as a function of irradiation time; $\mathrm{H}_{2} \mathrm{O}$ and pure gold nanoparticles as controls. 

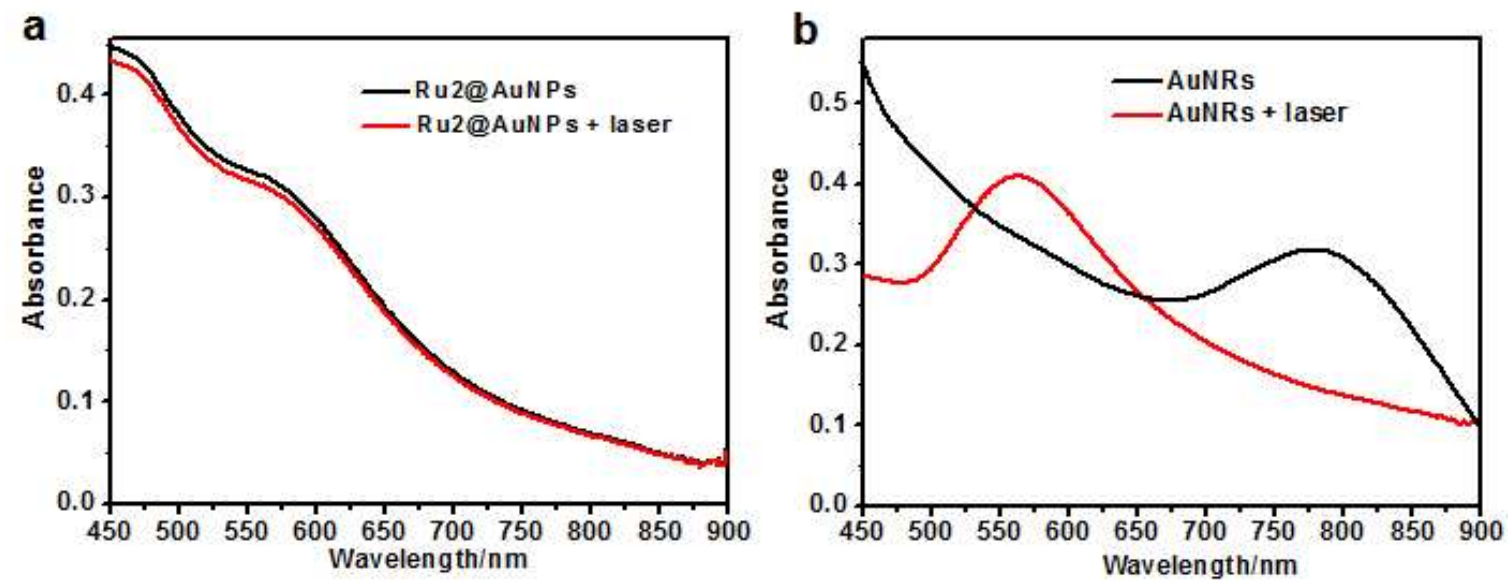

C
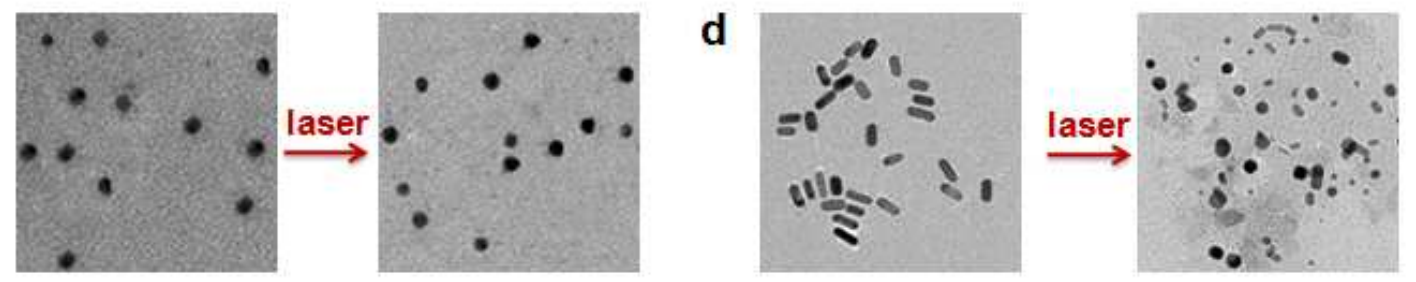

Fig. 5. UV-vis-NIR absorption spectra of the Ru2@AuNPs (a) and of the AuNRs (b) in the aqueous solution, and TEM images of the Ru2@AuNPs (c) and of the AuNRs ( d) morphology before and after $808 \mathrm{~nm}$ laser irradiation $\left(0.8 \mathrm{~W} / \mathrm{cm}^{2}, 30 \mathrm{~min}\right)$. 

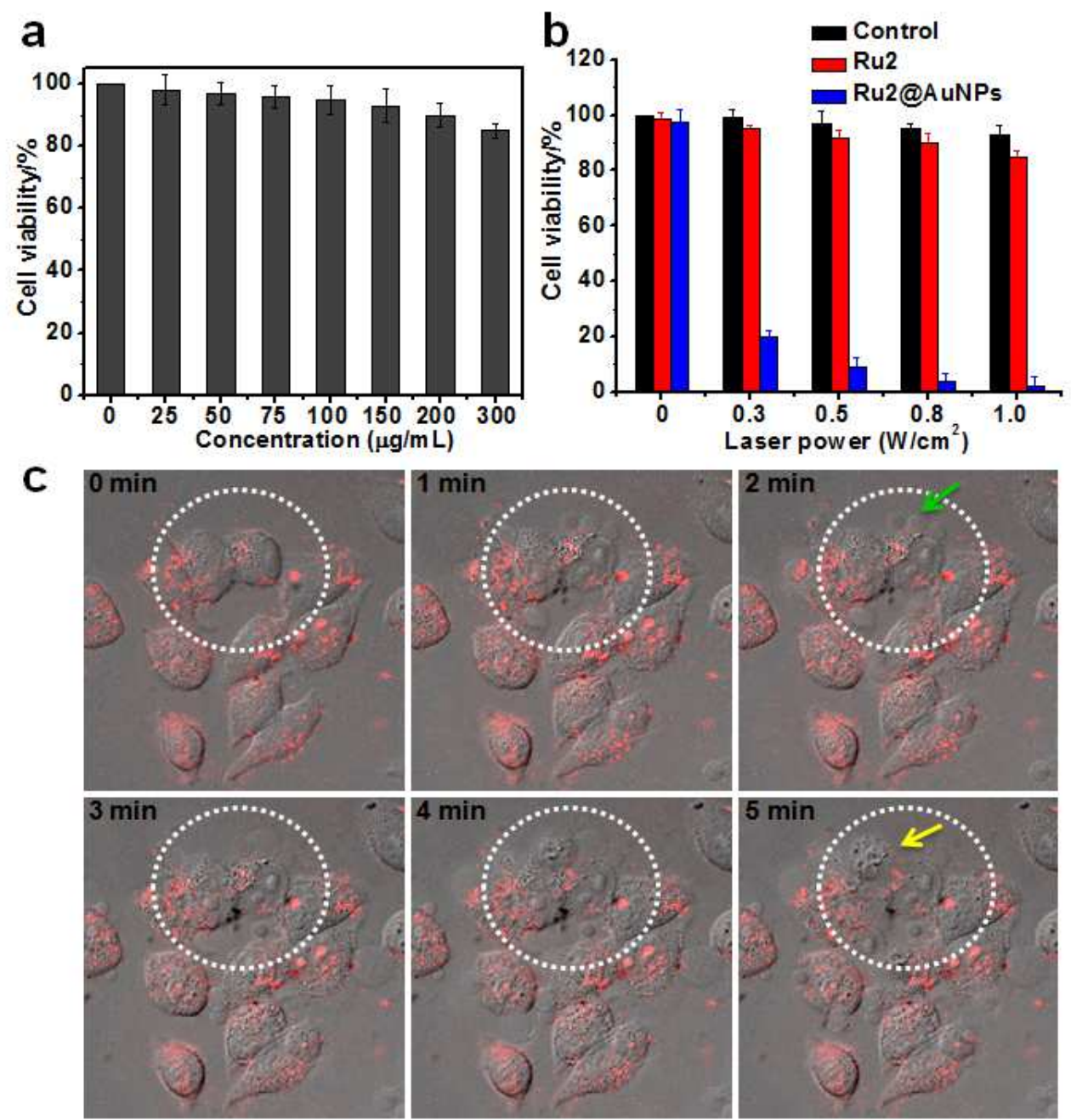

Fig. 6. a) Cell viability of HeLa cancer cells after treatment with different concentration

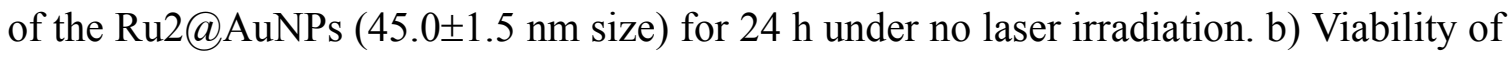
HeLa cells after Ru2@AuNPs $(45.0 \pm 1.5 \mathrm{~nm}$ size, $50 \mu \mathrm{g} / \mathrm{mL})$ induced photothermal therapy upon $808 \mathrm{~nm}$ irradiation at different laser power densities. The $\mathbf{R u} 2$ complex was included as a control. c) Real-time two-photon luminescence images of the Ru2@AuNPs $(45.0 \pm 1.5 \mathrm{~nm}$ size, $50 \mu \mathrm{g} / \mathrm{mL})$ in HeLa cells measured by laser scanning confocal microscope after different irradiation times $\left(808 \mathrm{~nm}, 0.8 \mathrm{~W} / \mathrm{cm}^{2}, 0-5 \mathrm{~min}\right)$. White circle indicates the laser spot. Membrane blebbing (green arrow) and apoptotic bodied (yellow arrow) were observed. 
a

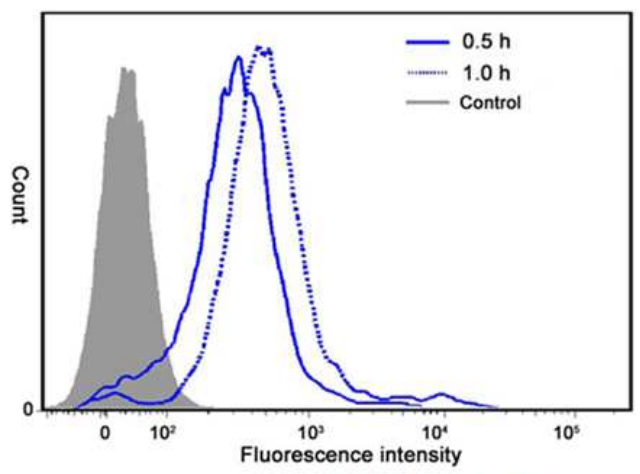

C
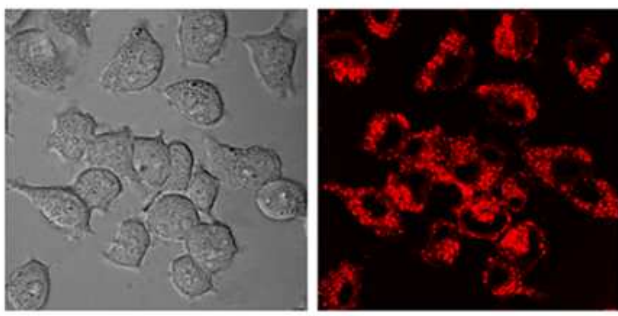

d

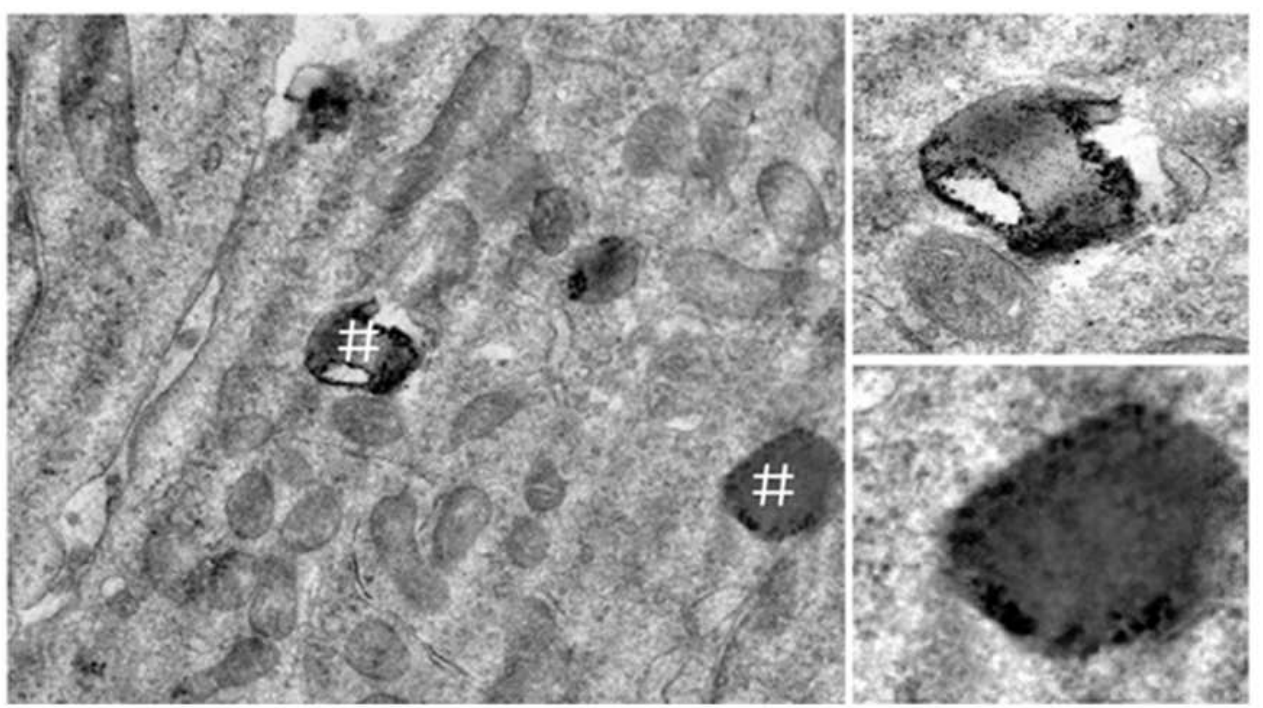

Fig. 7. Cellular uptake analysis of the Ru2@AuNPs by a) flow cytometry b) ICP-MS; c) Confocal fluorescence microscopy (from left to right: bright field, Ru@AuNPs' two-photon luminescence, Hoechst 33258 luminescence and overlay images); d) TEM images show that the Ru2@AuNPs form an endosome (white \#) after entering the cell; HeLa cells incubated with the Ru2@AuNPs $(50 \mu \mathrm{g} / \mathrm{mL})$ at $37{ }^{\circ} \mathrm{C}$ for $1 \mathrm{~h}$. 

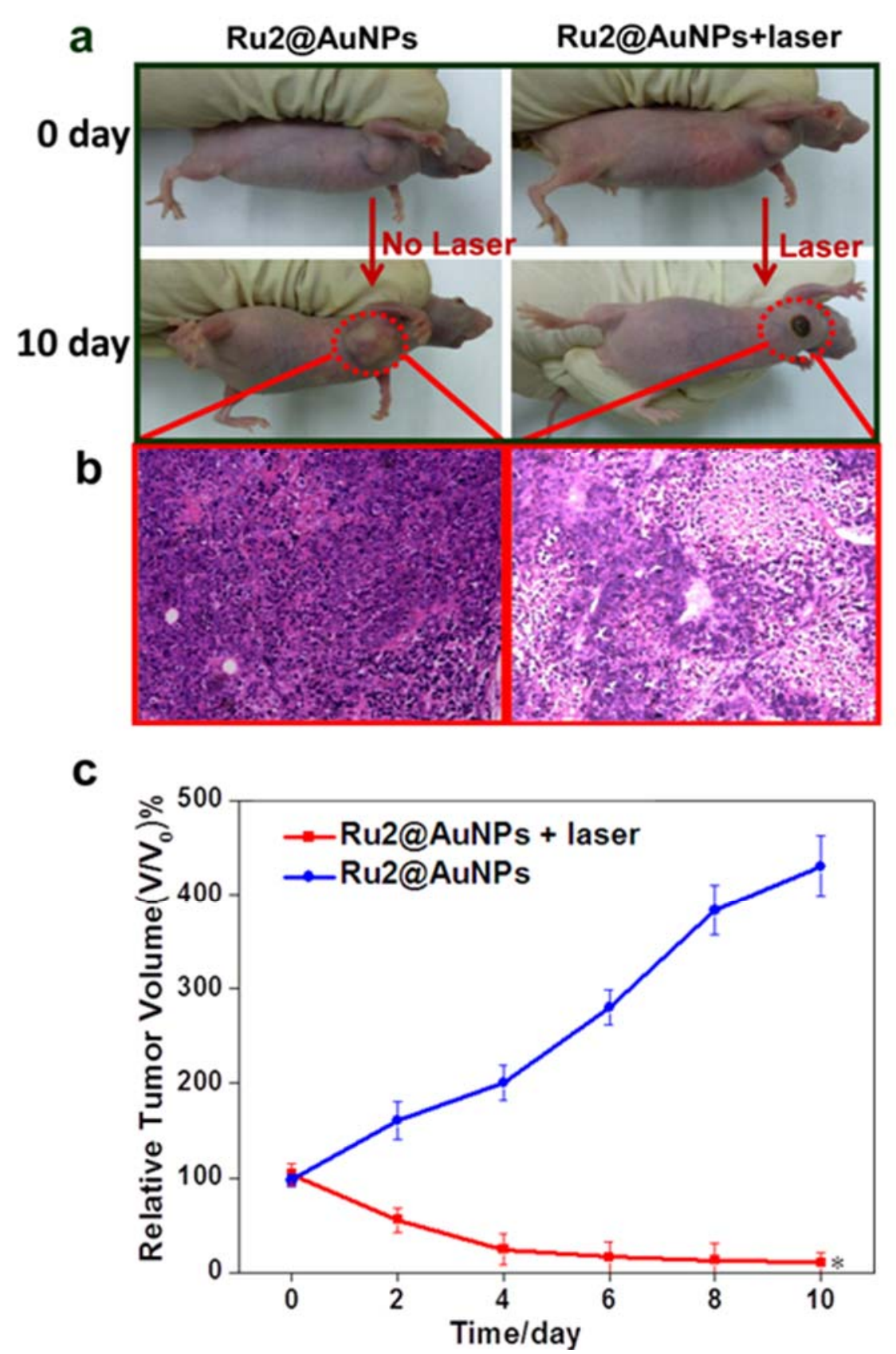

Fig. 8. a) Representative photographs of HeLa tumors in mice in the presence of the Ru2@AuNPs without/with 808 nm laser treatments $\left(0.8 \mathrm{~W} / \mathrm{cm}^{2}, 5 \mathrm{~min}\right)$. b) Histological examination of tumors without/with laser treatments on day 10. c) The tumor growth curves for the two mice groups after treatment. The dose was $200 \mu \mathrm{g}$ nanoparticles per 20 g mouse body weight. Tumor volumes were normalized to their initial sizes. Error bars represent the standard deviation of 8 mice per group. $*=p<0.01$, compared with the Ru2@AuNPs group. 